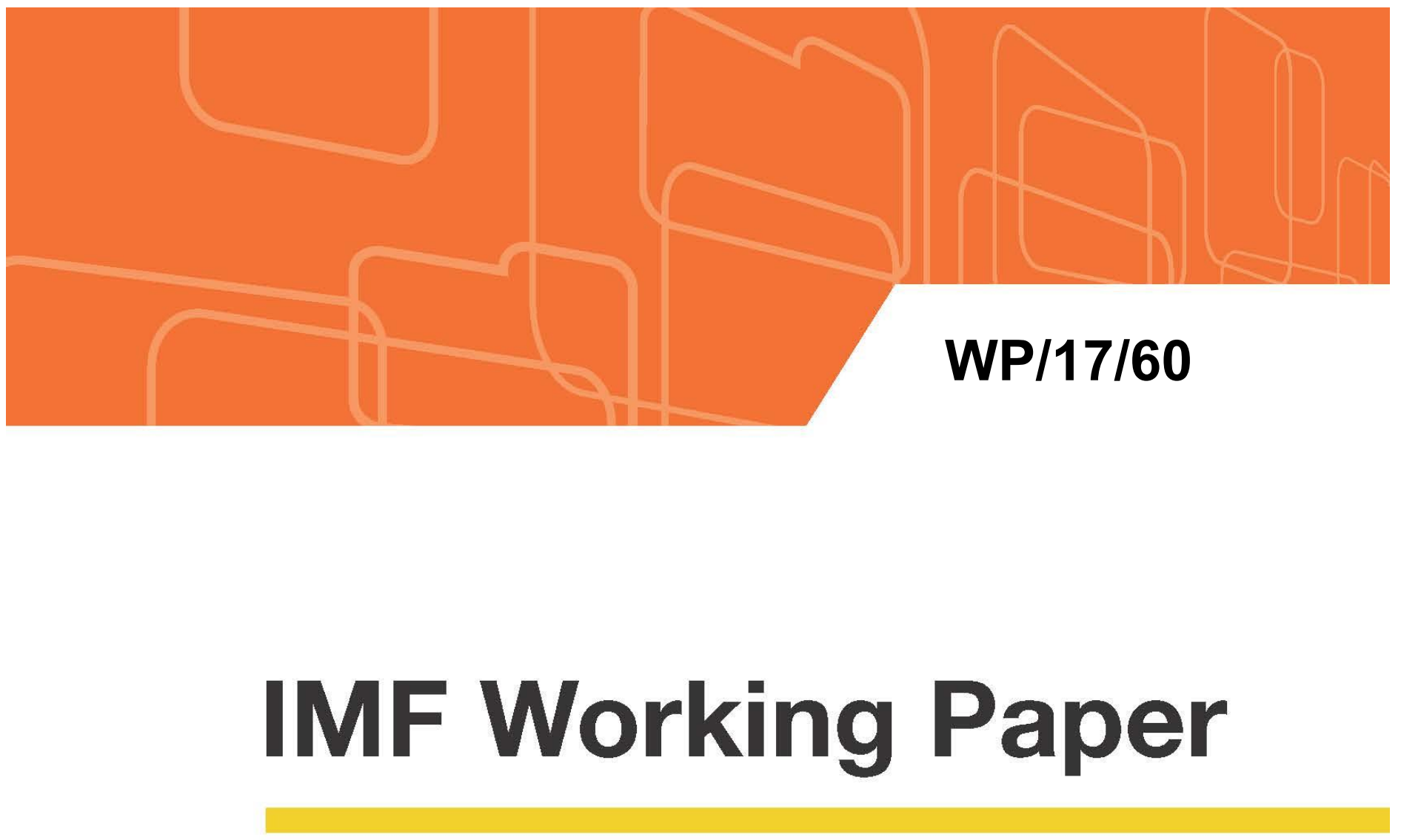

\title{
Bank Ownership: Trends and Implications
}

by Robert Cull, Maria Soledad Martinez Peria and Jeanne Verrier

IMF Working Papers describe research in progress by the author(s) and are published to elicit comments and to encourage debate. The views expressed in IMF Working Papers are those of the author(s) and do not necessarily represent the views of the IMF, its Executive Board, or IMF management.

$$
\text { I N TER N A T I O N A L M O N E T A R Y F U N D }
$$


IMF Working Paper

Research Department

Bank Ownership: Trends and Implications*

Prepared by Robert Cull, Maria Soledad Martinez Peria and Jeanne Verrier ${ }^{\dagger}$

Authorized for distribution by Giovanni Dell'Ariccia

March 2017

\begin{abstract}
IMF Working Papers describe research in progress by the author(s) and are published to elicit comments and to encourage debate. The views expressed in IMF Working Papers are those of the author(s) and do not necessarily represent the views of the IMF, its Executive Board, or IMF management.
\end{abstract}

\begin{abstract}
This paper presents recent trends in bank ownership across countries and summarizes the evidence regarding the implications of bank ownership structure for bank performance and competition, financial stability, and access to finance. The evidence reviewed suggests that foreign-owned banks are more efficient than domestic banks in developing countries, promote competition in host banking sectors, and help stabilize credit when host countries face idiosyncratic shocks. But there are tradeoffs, since foreign-owned banks can transmit external shocks and might not always expand access to credit. The record on the impact of government bank ownership suggests few benefits, especially for developing countries.
\end{abstract}

JEL Classification Numbers: F23, F36, F65, G21, G28, G34

Keywords: bank governance, financial globalization, foreign banks, state-owned banks, privatization

Author's E-Mail Address: rcull@worldbank.org; mmartinezperia@imf.org; jeanne.verrier@gmail.com

\footnotetext{
* This paper was prepared for a chapter of the forthcoming Handbook of Finance and Development edited by Thorsten Beck and Ross Levine to be published by Edward Elgar.

${ }^{\dagger}$ Robert Cull is with the World Bank, Maria Soledad Martinez Peria is with the International Monetary Fund and Jeanne Verrier is with the Graduate Institute, Geneva. The authors would like to thank Subika Farazi and Xiaojing Zhou for sharing their data. The views expressed in this paper are not those of the World Bank, its management, or Executive Directors.
} 


\section{Table of Contents}

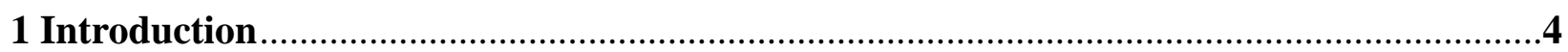

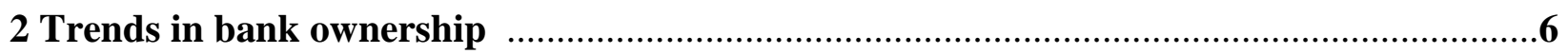

3 Bank ownership, performance and competition in the domestic banking sector .............10

The evidence on foreign bank ownership .......................................................................10

The evidence on government bank ownership ................................................................14

4 Bank ownership and banking sector stability ........................................................18

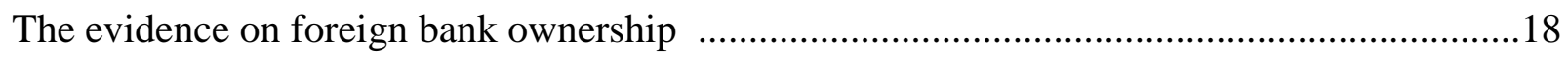

The evidence on government bank ownership .............................................................21

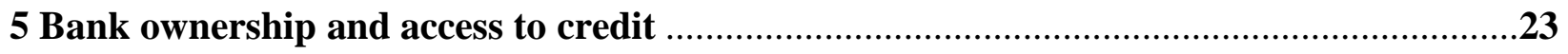

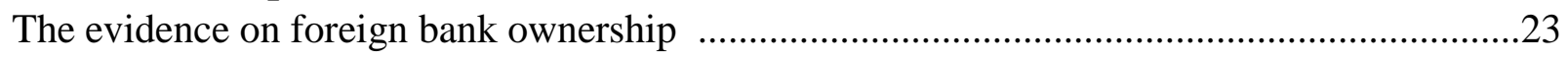

The evidence on government bank ownership ............................................................27

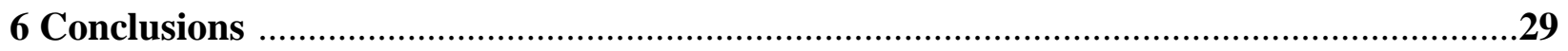

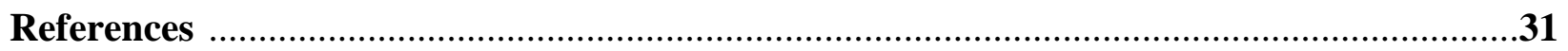

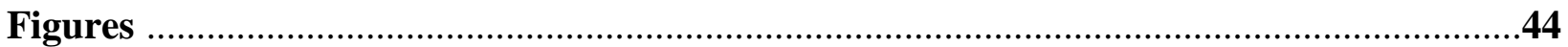

Figure 1.1. Share of assets owned by foreign banks, 2012-2013 ........................................44

Figure 1.2. Share of assets owned by government banks, 2010 ..........................................44

Figure 2.1. Asset share of foreign-owned banks by income group, 1995-2013.....................45

Figure 2.2. Asset share of government-owned banks by income group, 1995-2010 ..............45

Figure 3.1. Median asset share of foreign-owned banks in developing countries by region,

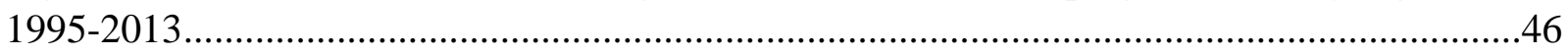

Figure 3.2. Median asset share of government-owned banks by region, 1995-2010..............46

Appendix ..........................................................................................................................

Table A.1. Foreign and government ownership by country, 1995-2013 ..............................47 


\section{Introduction}

The rise in financial globalization since the 1990s led to significant changes in bank ownership structures around the world. ${ }^{1}$ Across both developed and developing countries the share of banks owned by foreigners increased, while at the same time government ownership of banks declined. The recent Global Financial Crisis (GFC) reignited the debate on the ownership structure of the banking sector and its consequences for financial intermediation. Some have pointed to the presence of foreign-owned banks in developing countries as a key mechanism for transmitting the 2008-2009 crisis from advanced to developing countries (e.g., IMF, 2009). At the same time, developing countries such as Brazil, China, and India, where government-owned banks are systemically important, recovered quickly from the crisis, generating interest in the potential mitigating role that these banks can play during periods of financial distress. ${ }^{2}$

The rationale for, and impact of, government and foreign bank ownership is a controversial subject. There are two benign views of government-owned banks. The "social" view stresses that by helping to overcome market failures and taking advantage of externalities, government-owned banks can promote socially desirable welfare enhancing investments (Atkinson and Stiglitz, 1980; Stiglitz, 1993). The related "development" view underscores that government-owned banks can play a crucial role in allocating resources to strategically important industries that the private sector is unable or unwilling to finance, hence helping to jump start economic development (Gerschenkron, 1962). In contrast, there are two views that stress that government bank ownership can lead to resource misallocation and inefficiencies. According to

\footnotetext{
${ }^{1}$ Broader trends in global capital market integration are discussed by Lane and Milesi-Ferretti $(2001,2007)$ and Obstfeld and Taylor (2004).

${ }^{2}$ See for example the discussion in the following articles: "They Must Be Giants," The Economist, May 15, 2010. "Falling in Love with the State Again," The Economist, April 3, 2010. "Not Just Straw Men," The Economist, June 20, 2009.
} 
the "agency view," even when the government has the best of intentions, the agency costs associated with a government bureaucracy (i.e., the conflict of interest between the government and the bureaucrats designated to manage government-owned banks) can give rise to operational inefficiencies and misallocation (Banerjee, 1997; Hart et al., 1997). The "political" view suggests that government-owned banks are a mechanism for politicians to pursue their own goals (e.g., reelection, personal profit, etc.) resulting in resource misallocation (e.g., financing of supporters or of those willing to pay the highest bribes) and economic inefficiency (Shleifer and Vishny, 1994; Shleifer, 1998). ${ }^{3}$ Related to this view, political economy models suggest that politicians are more likely to favor government bank ownership when public accountability and judicial independence are low, since politicians can extract benefits with no personal consequences (Perotti and Vorage, 2010).

The main arguments in support of foreign bank ownership are that foreign banks can bring capital, technical skills, and product innovation (in particular to developing countries), fostering increased competition and improvements in the efficiency of the banking sector (Levine, 1996; Goldberg, 2004). ${ }^{4}$ On the other hand, the commonly mentioned criticism of foreign-owned banks is that they can destabilize the local banking sector by transmitting external shocks and threatening the survival of local banks by increasing competition (Stiglitz, 1994). ${ }^{5}$ Finally, foreign-owned banks can lead to reduced access to finance for a majority of domestic

\footnotetext{
${ }^{3}$ Perotti (1994) describes how by reducing the effective control of politicians over banks, privatization helps to depoliticize bank lending and resource allocation. Even when politicians may still intervene to pressure privatized firms, privatization establishes some restraint as it transfers a set of residual rights to the private owners. ${ }^{4}$ Despite the potential benefits of foreign bank ownership, most accounts of the political economy of banking market opening stress that governments that allow foreigners to hold a significant share of banking system assets do so under duress (Epstein, 2014). They may, for example, be undergoing a severe banking crisis (Haber, 2005; Martinez-Diaz, 2009), trying to gain international credibility or generally in need of international assistance (see Epstein 2008, Stein 2010).

5 They can either import shocks from their home countries and/or spread shocks from other developing countries in which they operate.
} 
firms and consumers if they only concentrate on the least risky and most transparent segment of the market (Detragiache et al., 2008).

This paper describes the recent changes in bank ownership and summarizes the evidence on the impact of different bank ownership structures. Because empirical studies analyzing the consequences of bank ownership do not always distinguish between private domestic, government- and foreign-owned banks, it is hard to compare results across studies that only compare government- or foreign-owned banks to all other banks. Hence, in each section, we summarize the evidence on foreign and government bank ownership separately.

The remainder of the paper is organized as follows. Section 2 discusses the trends and regional patterns in foreign and government bank ownership. Section 3 summarizes the literature on bank ownership, performance, and competition. Section 4 presents the existing evidence on whether bank ownership structures affect financial stability. The literature on the impact of bank ownership on access to finance is presented in Section 5. Finally, Section 6 concludes.

\section{Trends in bank ownership}

Today foreign-owned banks play a dominant role in many banking systems across the world (Figure 1.1). In contrast, government-owned banks are key players in many fewer countries, though a handful of them (China, India, Russia) are large ones (Figure 1.2). On average, foreign-owned banks account for 43 percent of total banking assets across all countries. In contrast, government-owned banks represent only 18 percent of banking system assets. Beyond these aggregate statistics, however, ownership structures vary substantially across economies. Table A.1 in the Appendix shows the share of assets held by foreign- and government-owned banks in a sample of 93 countries across the world. Countries tend to share 
common structural features within regions: while foreign-owned banks play strong roles in Latin America, Sub-Saharan Africa, and Eastern Europe \& Central Asia, government-owned banks are prevalent in South Asia and Middle East \& North Africa.

Changes in bank ownership structures followed more or less monotonic trends from the 1990s up to the GFC. Foreign bank participation increased uninterruptedly in the context of the post-communist transition, waves of bank privatizations, liberalization reforms, and rapid financial globalization. For developing countries, the median (average) share of assets owned by foreign banks rose from 8 (16) percent in 1995 to 35 (40) percent at the end of the 1990s and reached 52 (50) percent by 2010. Across high-income countries, the median (average) share of assets held by foreign-owned banks rose from 5 (15) percent in 1995 to 12 (28) percent by the end of the decade, reaching 27 (43) percent in 2008 (Figure 2.1). In contrast, the asset shares of government-owned banks followed a downward trend in all regions. Developing countries experienced a decline in the median (average) share of bank assets held by government-owned banks from 40 (40) percent in 1995 to 8 (17) percent in 2008. Among high-income countries, the median (average) share of assets held by government-owned banks fell from 30 (36) percent in 1995 to 4 (10) percent in 2008 (Figure 2.2).

The GFC disrupted the trends discussed above. Between 2008 and 2010, the average (median) share of assets held by foreign-owned banks fell by 0.2 (3.1) percentage points in developing countries and by 1.6 (2.2) percentage points in high-income countries (Figure 2.1). ${ }^{6}$ This retrenchment at the onset of the crisis can be explained in part by the propagation of shocks across borders by global banks, but also by the fact that many financial institutions from crisis-

\footnotetext{
${ }^{6}$ Claessens and Van Horen (2015) documents that the share of foreign banks in the total number of banks remained constant in the wake of the GFC.
} 
affected countries repatriated their funds from abroad to make up for capital losses and to meet higher capital requirements that were imposed on them. In contrast, South-South cross-border investments in banking not only held up during the GFC, but grew subsequently. Banks from non-OECD countries recorded positive net foreign entries in every year between 2009 and 2013 and more than doubled their presence abroad, mostly in their own regions (Claessens and Van Horen, 2015).

In contrast with foreign banking, there has been a regained interest in government-owned banks, as many high-income and developing countries recapitalized or nationalized troubled banks following the GFC. Notable cases include Iceland, Kazakhstan, the United Kingdom, and Venezuela, where the share of assets held by the government in the banking sector increased by more than 10 percentage points between 2008 and 2010 (see Table A.1 in the Appendix).

These general trends mask important disparities across countries, although commonalities within regions are strong (Figures 3.1 and 3.2). In Latin America, Spanish banks bought local banks and gained significant market shares in the 1990s, following a wave of bank privatizations. Foreign-owned banks represent a sizable share of banking assets in the region (roughly $40 \%$ over 1999-2010), while the share of government-owned banks (roughly 13\% over 1999-2010) is just below the median for developing countries. The reliance of foreign-owned banks in Latin America on local funding and the relative independence of their subsidiaries explain their limited retrenchment at the onset of the GFC (Cull and Martinez Peria, 2013).

Banking systems in Eastern Europe and Central Asia are also characterized by high foreign bank and moderate government bank participation. The region recorded the world's fastest increase in foreign bank presence in the 1990s and early 2000s in the context of the 
massive privatizations of the post-USSR era. The median share of assets held by foreign-owned banks rose from 5 percent in 1995 to 60 percent by 2008. However, the foreign ownership share declined abruptly (from $60 \%$ in 2008 to $48 \%$ in 2010) as some Western banks faced drastic funding shortages and had to cut back their operations in the region. Government-owned banks filled part of this gap at the onset of the crisis. Their median asset share increased by 5 percentage points between 2008 and 2010 in Eastern Europe and Central Asia, the highest for any region.

In Sub-Saharan Africa, foreign-owned banks have been present since the colonial era and their participation increased following reforms that liberalized financial sectors in the 1990s and early 2000s. In particular, the median share of assets held by foreign-owned banks rose from 34 percent in 1995 to 66 percent in 2008. In 2010, the region had the highest median foreign bank share (73 percent) and lowest median government bank share ( 8 percent $)$ in the developing world. The fast expansion of banks from developing countries - in particular Pan-African banks headquartered in South Africa, Nigeria, Morocco, Kenya and Togo (Beck et al., 2014) - explains why foreign bank participation is still high after the progressive retrenchment of the old (predominantly Western) players from the region in the aftermath of the GFC.

On the other side of the spectrum, South Asia has the lowest share of foreign-owned banks and the highest share of government-owned banks among all regions across all years. Foreign bank participation in South Asia increased gradually beginning in the late 1990s (from 1 percent of banking assets in 1995 to 15 percent in 2008), when countries reduced government ownership and liberalized their banking sectors (Klapper, et al., 2014), but it still remains limited outside of Pakistan and the Maldives. Government bank ownership dropped substantially and uninterruptedly in South Asia from 72 percent in 1995 to 39 percent by 2010. 
In the East Asia and Pacific region, the crisis of the late 1990s forced governments to clean up, restructure, and open up their banking systems. In China, banking reforms introduced in 2001 also led the way to greater foreign bank participation. Across the region, the median share of assets held by foreign-owned banks rose from 8 percent in 1995 to almost 30 percent before the GFC. While the region suffered from sudden stops in capital flows during the recent crisis, global banks did not reverse their brick-and-mortar operations to the same extent as in other regions between 2008 and $2010 .^{7}$ At the same time, the share of assets held by governmentowned banks fell from 23 percent in 1995 to 13 percent by 2008.

\section{Bank ownership, performance and competition in the domestic banking sector}

\section{The evidence on foreign bank ownership}

The entry of foreign banks can affect the efficiency of the domestic banking sector. If foreign-owned banks are more efficient than domestic banks, competitive pressures may force the latter to lower their spreads and rationalize their cost structure, making them more efficient. A plethora of studies - at least fifty - compare the performance of foreign and domestic banks, with mixed results. Those results are sensitive to the estimation method (data envelopment, distribution free approaches or stochastic frontier analysis for the most part), but also to the multitude of performance measures (profitability ratios, cost and profit efficiency measures, and stability indicators).

\footnotetext{
${ }^{7}$ Data from the Word Bank Regulation and Supervision surveys document a slight increase in foreign ownership between 2008 and 2010. Figure 3.1 does however show a substantial decline in the share of assets held by foreign banks in East Asia and the Pacific from 2010 to 2012-13. As explained in the notes to the figure, the 2012-2013 numbers come from a different source than those for 2010, and cover fewer countries than the numbers for 2008 and 2010. We cannot therefore reliably claim that there was a substantial retrenchment in foreign bank presence in East Asia and the Pacific from 2010 to 2012-2013.
} 
Regional and country-level studies focusing on high-income countries mostly suggest that domestic banks outperform foreign banks (Berger et al., 2000; Miller and Parkhe, 2002), in particular in the United States (DeYoung and Nolle, 1996; Hasan and Hunter, 1996; Chang et al., 1998; Peek et al., 1999). In contrast, the majority of studies focusing on developing countries finds that foreign-owned banks perform better than the other types of banks in terms of cost and profit efficiency. This is the case in Eastern Europe and Central Asia where a considerable number of regional studies derive results consistent with that proposition (Bonin, Hasan and Wachtel, 2005; Fries and Taci, 2005; Grigorian and Manole, 2006; Havrylchyk and Jurzyk, 2011), ${ }^{8}$ as do country level studies of Poland and Czech Republic (Weill, 2003; Matousek and Taci, 2004; Havrylchyk, 2006), Hungary (Hasan and Marton, 2003; Majnoni, Shankar and Varhegyi, 2003), Croatia (Jemric and Vujcic, 2002; Kraft et al., 2006) and Turkey (Isik and Hassan, 2002). Similarly, in Asia, country case studies for Malaysia (Detragiache and Gupta, 2006; Matthews and Ismail, 2006), Thailand (Chantapong, 2005), Indonesia (Mulyaningsih, 2015) and Pakistan (Bonaccorsi di Patti and Hardy, 2005) find that foreign-owned banks are better performers. The findings are more ambiguous in China (Wu et al., 2007; Berger et al., 2009) and India (Bhattacharya et al. 1997; Sensarma, 2006), where foreign bank participation remains limited. The conclusions of studies from Latin America in the 1990s, however, vary with the measure of efficiency employed (Barajas et al., 2000; Goldberg et al., 2000; Crystal et al., 2001; Berger et al., 2005). Due to the lack of data from Sub-Saharan Africa and MENA, evidence from these two regions is scant. ${ }^{9}$

\footnotetext{
${ }^{8}$ On the contrary, Green et al. (2004a, 2004b) and Yildirim and Philippatos (2007) find no evidence or even counter-evidence that foreign-owned banks are relatively more efficient.

${ }^{9}$ Farazi et al. (2013) is one notable exception.
} 
Given the variability in results at the regional and country levels, studies based on large samples of countries are particularly helpful in this literature. Such studies find evidence that foreign ownership is associated with higher interest margins and profitability, and lower overhead costs, in developing host countries (Demirgüç-Kunt and Huizinga, 1999; Micco et al., 2007), while the opposite is true in high-income countries (Claessens et al., 2001). ${ }^{10}$ Controlling for heterogeneity across banks and countries helps reconcile these contradictory findings: foreign banks are relatively more profitable when they are from a high-income country, when they share the same language and a similar regulatory and supervisory framework with the host country, when regulations in the host country are weak, and when the foreign bank is larger in size and market share (Claessens and Van Horen, 2012).

Another strand of the literature does not directly compare the performance of domestic versus foreign banks, but rather examines how the extent of foreign ownership in a country affects the performance of the domestic banking sector by exerting competitive pressures. These studies find a negative relation between foreign banking and the performance of domestic banks (see Demirgüç-Kunt et al.,1998; Claessens et al., 2001; and Bayraktar and Wang, 2004). Claessens and Lee (2003) finds that similar results hold, on average, for the level of foreign bank participation, but also highlight threshold effects, showing that the effect of foreign bank presence on competitiveness is stronger in countries where foreign-owned banks have a higher market share.

Foreign entry may also affect the extent of competition in the domestic banking sector. Models of spatial competition have shown that foreign bank presence has a downward effect on

\footnotetext{
${ }^{10}$ Mian (2003) finds no significant difference in profitability across different types of ownership, but does not control for bank characteristics.
} 
the lending rate of local banks (Kaas, 2004; Park and Pennacchi, 2009), although specific market characteristics may lead both foreign and domestic banks to charge higher margins (Delis et al., 2016). The magnitude of the effect also depends on the mode of entry. Foreign bank participation should lead to fiercer price competition when foreign banks enter through greenfield investments, which increase the number of banks and decrease market power. In contrast, in some cases acquisitions by foreign banks can result in greater concentration and market power, and lower competition (Lehner and Schnitzer, 2008). Models of asymmetric information reach similar conclusions regarding the mode of entry by showing that competition depends on the distribution of information about incumbent customers between domestic and foreign banks (Van Tassel and Vishwasrao, 2007; Claeys and Hainz, 2014).

A first approach in analyzing how foreign bank ownership affects the degree of competition in the domestic banking sector uses direct and nonstructural measures of competition like the Panzar-Rosse (1987) H-statistic. Early evidence from cross-country datasets suggests that there is a positive relation between foreign ownership and competition (Claessens and Laeven, 2004; Gelos and Roldos, 2004), while a subsequent study that focuses on Latin America yields opposite results (Levy-Yeyati and Micco, 2007). Controlling for banking system characteristics helps reconcile contradictory findings: the link between foreign bank participation and competition is found to be positive and more significant when the entering banks are more efficient and less risky and when the host banking sector is less concentrated. ${ }^{11}$ The mode of

\footnotetext{
${ }^{11}$ Efficiency and riskiness are respectively defined at the bank-level by the ratio of non-interest expenses to total assets and by the ratio of loan loss provisions to total loans.
} 
entry also matters: the positive effect of foreign bank penetration on competition is stronger with greenfield investments than with mergers and acquisitions (Jeon et al., 2011). ${ }^{12}$

Moving away from the analysis of competition using the H-statistic, a very recent paper (Delis et al., 2016) measures market power at the bank level via the Lerner index to examine the impact of the ownership status (foreign or domestic) of individual banks on their own market power (direct effect), as well as the impact of the ratio of the number of foreign-owned banks to the total number of banks in the industry (spillover effects). The study, which uses bank-level data for 131 countries over 1997-2009, finds no evidence of a direct impact of bank ownership on market power. On the other hand, it finds that greater foreign bank presence has a positive effect on overall levels of market power in the banking sector, an empirical result that the authors explain by the fact that foreign banks enter mainly through mergers and acquisitions rather than greenfield investments

\section{The evidence on government bank ownership}

State ownership of banks also affects competition in the banking sector. It can in theory spur competition if state-owned banks are more efficient than private banks and push them to lower prices. However, the experience in developing countries is that high agency costs in stateowned banks lead to operational inefficiencies and low intermediation quality, which strongly limits their power to exert competitive pressures. The literature on government bank ownership and competition employs similar approaches to those used in the literature on foreign bank ownership and, likewise, yields mixed results. As in the literature on foreign bank ownership,

\footnotetext{
${ }^{12}$ The intuition offered by the authors of this study is that greenfield banks tend to be more aggressive in terms of pricing when they enter new markets so as to gain market share.
} 
some studies analyze the relative performance of government-owned banks while others investigate the impact of government bank ownership on the performance of domestic banks.

The first strand of the literature explores the link between government ownership and competition by looking at the performance of government-owned banks relative to privatelyowned banks. Within this literature, regional studies present evidence that government-owned banks perform worse than both private domestic and foreign banks. Latin America is one of the regions where the difference is found to be the strongest (Micco et al., 2007). The relative efficiency (proxied by overhead costs, non-performing loans and returns) is particularly low in Colombia and Honduras, although the opposite results are found in Costa Rica (Levy Yeyati et al., 2007).

Government-owned banks are also found to underperform in South and South-East Asia (Williams and Nguyen, 2005; Micco et al., 2007; Cornett et al., 2010). These findings are confirmed by case studies of Pakistan (Bonaccorsi di Patti and Hardy, 2005) and China (Berger et al., 2009), while the opposite results are found in India where government-owned banks represented 78 percent of banking system assets at the turn of the century (Sensarma, 2005).

In the MENA region, state-owned banks have lower interest margins, higher cost ratios, larger NPLs, larger loan loss provisions, and lower profitability than private domestic non-listed banks, a result that can be attributed to a combination of policy mandates and operational inefficiencies (Farazi et al., 2013). Regional studies of banks in Central and Eastern Europe in the 1990s find that government-owned banks are less cost efficient than private (domestic and foreign) banks, but the pattern is reversed in terms of profit efficiency (Bonin et al. 2005a, 2005b; Yildirim and Philippatos, 2007). 
Finally, government-owned banks in Western Europe exhibited lower profitability and cost efficiency than privately-owned banks from 1999 to 2004, despite lower costs of funding (Ianotta et al., 2007). In contrast, case studies of Germany (where government-owned banks represented 42 percent of banking assets in 2000) show that government-owned banks have a profit and cost advantage, which is not the result of their alleged unfair advantage in the cost of borrowing funds (Altunbas et al. 2001; Chakravarty and Williams 2006).

Studies based on large samples of countries also suggest that government-owned banks underperform in developing countries. This is consistent with the predictions of political economy models such as Perotti and Vorage (2010) (cf Section 1) and with the fact that the objective function of government-owned banks in developing countries is primarily to fulfill a development mandate rather than to maximize profits (Micco et al., 2007). Mian (2003) was the first to systematically compare the efficiency of government-owned banks, foreign-owned banks and domestic private banks in a large panel of emerging countries, finding that governmentowned banks had a significantly lower return on loans and higher rates of loan default despite lower deposit costs. These results are confirmed by Micco et al. (2007), which reduces endogeneity concerns by including country fixed effects, and finds that the difference in profitability, nonperforming loans and overhead costs is significant only in developing countries. To our knowledge, no cross-country study to date analyzes in a systematic way how the relative performance of government-banks varies with home and host country conditions, as well as bank characteristics. 
Another approach to studying the relative efficiency of government-owned banks focuses on estimating the efficiency gains or losses associated with bank privatizations. ${ }^{13}$ Cross-country studies in South East Asia and in a panel of 22 developing countries suggest that bank privatization raises bank profitability and efficiency over time to levels in excess of preprivatization bank performance, even when the acquirer is a foreign bank (Boubakri et al., 2005; Williams and Nguyen, 2005). Country case studies of Nigeria, Pakistan and China corroborate these results (Beck et al., 2005; Bonaccorsi di Patti and Hardy, 2005; Berger et al., 2009). Berger et al. (2005) proposes a methodology to address the common misspecification issues in this literature and, applying this methodology to data from Argentina, confirms that privatizations are associated with significant improvements in bank performance. ${ }^{14}$

In another strand of the literature, which investigates the impact of government bank ownership on domestic banks, a first line of research focuses on efficiency. Studies from the early 2000s provide some evidence that government ownership is negatively associated with domestic banking sector efficiency, as measured by net interest margins and overhead costs (Barth et al., 2001; La Porta et al., 2002). However, controlling for cross-country differences in regulatory and supervisory characteristics such as capital regulations, official supervisory practices, incentives for private monitoring, and restrictions on bank entry and activities, leads to insignificant results (Barth et al., 2004).

An alternative line of research focuses on stock market performance. Case studies of two public banks in Hong Kong and Australia show that their privatizations had a negative impact on the stock market performance of their competitors in the private sector, consistent with the

\footnotetext{
${ }^{13}$ See Megginson (2005) and Clarke et al. (2005a) for detailed reviews of this literature.

${ }^{14}$ For example, Berger et al. (2005) shows that results are sensitive to whether all categories of bank ownership (foreign, private domestic, and government) and changes in bank ownership are controlled for in their regressions.
} 
hypothesis that government bank ownership undermines competition (Otchere and Chan, 2003;

Chen et al., 2005). Another study analyzing abnormal returns in a cross-country setting comes to the same conclusion (Otchere, 2005).

\section{Bank ownership and banking sector stability}

The evidence on foreign bank ownership

In principle, foreign banks can have a stabilizing or destabilizing influence on the host banking sector, depending on the nature of the shocks that hit the host economy. If shocks are domestic in nature, then foreign banks can play a stabilizing role because they have access to liquidity and capital from their parents. Also, by virtue of having international operations, foreign banks are typically more diversified than domestic banks and, hence, should be less affected by domestic shocks. ${ }^{15}$ At the same time, however, foreign banks can import shocks from abroad, either from their home country or from other countries where they have significant operations. This, in turn, can destabilize the host banking sector. Similarly, by increasing competition in the domestic sector, the presence of foreign banks could potentially increase instability by pushing domestic banks to riskier segments or out of business altogether. ${ }^{16}$

A number of empirical studies show that foreign bank participation can have a stabilizing impact on the host bank sector by reducing the incidence of crises or by continuing to extend credit during such episodes. Cross-country evidence from 80 developed and developing countries

\footnotetext{
${ }^{15}$ Note that this statement presumes that the foreign banks entering the market are international banks with diversified operations and that domestic banks are exclusively local. The situation is different if both foreign and domestic banks are internationally diversified or have regional exposures, since then both domestic and foreign banks would be less exposed to domestic shocks.

${ }^{16}$ See discussion in section 3 .
} 
over 1988-1995 suggests that greater foreign bank presence is associated with a lower probability of systemic banking crises in the host country (Demirguc-Kunt et al., 1998). Subsequent research on a broader sample of 107 countries shows that official barriers to foreign bank entry are associated with measures of banking system fragility (Barth et al., 2004).

Another strand of the literature focuses on the response of foreign banks during crises in host countries. Bank-level studies find that in Eastern European countries (De Haas and Van Lelyveld, 2006), as well as in a broader sample of countries (De Haas and Van Lelyveld, 2010), ${ }^{17}$ credit growth by greenfield foreign banks is more resilient than that by (private) domestic banks during domestic crisis episodes. Similarly, in Latin America and Asia over 1989-2001, research shows that foreign banks' lending and deposits rates are less volatile than those of domestic banks in times of crisis (Arena et al, 2007).

Studies focusing on foreign banks' actions in specific countries and during particular host country crises confirm the cross-country finding that foreign banks can have a stabilizing influence. Case studies of Argentina, Brazil, and Mexico from 1994 to 1999 indicate that foreign banks do not pull back from host countries when these face economic problems, but rather view those difficulties as an opportunity to become more firmly rooted in those economies (Peek and Rosengren, 2000a). And in fact, in Argentina and Mexico, foreign banks had higher growth rates and lower volatility of lending than domestic banks during the crises of the mid to late 1990s (Dages et al., 2000). More generally, foreign banks in Latin American countries (Argentina, Brazil, Chile, Mexico, Peru, and Venezuela) showed more robust loan growth, a more aggressive response to asset deterioration, and greater ability to absorb losses than did domestic banks during this period (Crystal et al., 2001, 2002). A study of Malaysian banks around the time of the

\footnotetext{
${ }^{17}$ The dataset includes 45 multinational banks from 18 home countries with 194 subsidiaries across 46 countries.
} 
Asian crisis comes to a more nuanced conclusion regarding the behavior of foreign-owned banks: diversified foreign banks played a stabilizing role during the crisis in Malaysia (Detragiache and Gupta, 2006). In particular, banks that were not specialized in Asia continued to lend and had substantially higher profits and less non-performing loans than domestic banks and foreign banks that were mainly active in the region.

While, as described above, many studies find that foreign banks can mitigate the impact of host-grown crises, the literature also suggests that foreign banks can act as external shock amplifiers. Exploiting the collapse in Japanese stock prices as an exogenous shock to the U.S. banking sector, Peek and Rosengren $(1997,2000 \mathrm{~b})$ were among the first studies to show that shocks can be transmitted across borders through global banks. In particular, in response to the decline in stock prices in Japan, these studies show that U.S. branches of Japanese banks reduced lending in the US. In the same vein, Chava and Purnanandam (2011) and Schnabl (2012) use the exogenous shock provided by the 1998 Russian crisis and derive similar results on the effects on bank lending to borrowers in the United States and Peru, respectively. ${ }^{18}$

The recent GFC offers a unique opportunity to ascertain how foreign bank lending reacted to a major, global external shock. Overall, the evidence suggests that foreign banks reduced their lending earlier and faster than domestic banks during the crisis (Aiyar, 2012; Fungáčová et al., 2013; de Haas and van Lelyveld, 2014, Claessens and van Horen, 2015; Choi et al., 2016), in particular within Eastern Europe (Mihaljek, 2011; de Haas et al., 2015). But there

\footnotetext{
${ }^{18}$ A related literature analyzes the effect of banks' geographic expansion on stability in the context of the U.S. interstate banking deregulation process that started in the late 1970s. Consistently with the findings of the international banking literature, the U.S. laboratory provides evidence that banks can act as shock absorbers or shock amplifiers by moving resources across branches following local demand shocks (e.g. Cortes and Strahan, 2014; Gilje et al., 2016), and local supply shocks (e.g. Campello, 2001; Ashcraft, 2006; Huang, 2008). The effect of bank integration on state-level business cycle volatility and business cycle synchronization depend on the nature of the shock (Morgan et al., 2004; Goetz and Gozzi, 2014; Loutskina and Strahan, 2015).
} 
are heterogeneous effects, depending on country- and bank-level characteristics. Evidence from cross-country studies suggests that the transmission of shocks is stronger in host countries that are less regulated (Anginer et al., 2017), more financially open, and where there is more competition in the banking sector (Jeon et al., 2013). The degree of transmission is also found to be stronger for foreign-owned banks with lower levels of capital, profitability, retail funding, and less independent management (Popov and Udell, 2012; Jeon et al., 2013; de Haas and Van Lelyveld, 2014, de Haas et al., 2015; and Anginer et al., 2017; Choi et al.,2016). Finally, the transmission of shocks is stronger when banks entered host markets via greenfield investment rather than M\&A (Jeon et al., 2013).

Recent research has not only informed the debate on whether and when global banks transmit shocks, but has also furthered our understanding of how this happens. Studies such Cetorelli and Goldberg (2012a, 2012b, 2012c) and Jeon et al. (2013) provide evidence of the existence of an active cross-border internal capital market, whereby global banks reallocate funds across their branches and subsidiaries to buffer shocks to the parent bank balance sheet.

\section{The evidence on government bank ownership}

The evidence on whether government bank ownership is directly related to the incidence of banking crises is limited and mixed. In a sample of 64 countries over 1980-1997, Caprio and Martinez Peria (2002) finds that government bank ownership is positively associated with the likelihood of banking crises. La Porta, Lopez de Silanes and Schleifer (2002) also studies the correlation between government bank ownership and the incidence of banking crises, but does not find significant results. Barth et al. (2004) finds a positive bi-variate correlation between banking crises and government ownership, but this association does not survive after controlling 
for regulatory and supervisory environment features. Since Barth et al. (2004) also finds that bank regulations and supervisory practices are closely associated with the degree of government ownership of banks, the study argues that the induced multi-collinearity produces insignificant coefficients on government ownership.

The association between government bank ownership and other measures of financial instability appears to be more robust. In particular, a number of studies have found that government-owned banks operating in developing countries have a higher fraction of nonperforming loans than privately-owned banks (Micco et al., 2004; IADB 2005; Iannotta et al., 2007; Berger et al., 2009; Farazi et al., 2011). Moreover, government-owned banks also tend to display a higher likelihood of default as captured by a lower Z-score.

There are also many studies that have found that government-owned banks can lead to a misallocation of resources, since they are subject to political manipulation and tend to increase lending to politically strategic sectors or regions near elections (see, e.g., Sapienza, 2004 for evidence on Italy; Khwaja and Mian, 2005 for evidence on Pakistan; Cole, 2009a,b for evidence on India; Carvalho, 2014 for evidence on Brazil). Moreover, there is also evidence that government-owned banks target firms that have political ties to the detriment of other firms (Khwaja and Mian, 2005; Claessens et al., 2008; Carvalho, 2014).

While the bulk of the evidence presented so far suggests that government-owned banks can have a destabilizing impact on the financial sector, there is also evidence that government bank lending could be beneficial during downturns. In particular, a number of studies have shown that government bank lending is less procyclical than private bank lending whether focusing primarily on the pre-GFC period (Micco and Panizza, 2006; Foos, 2009; Brei and 
Schclarek, 2013; Onder and Ozyldirim 2013; Bertay et al. 2015; Duprey, 2015) ${ }^{19}$ or analyzing specifically the behavior of government-owned banks during the GFC period (Leony and Romeu 2011; Cull and Martinez Peria, 2013; Coleman and Feler, 2015; De Haas et al., 2015; Chen et al., 2016; Choi et al., 2016; Allen et al., forthcoming). The evidence for the GFC period, however, is mixed when it comes to the behavior of government-owned banks in Eastern Europe (see Cull and Martinez Peria, 2013; De Haas et al, 2015; Allen et al., forthcoming).

\section{Bank ownership and access to credit}

\section{The evidence on foreign bank ownership}

A common assumption underlying theoretical work on foreign bank lending is that foreign banks are at an informational disadvantage relative to domestic banks in lending to local, and, in particular, informationally opaque borrowers in a host country. In other words, due to better knowledge of local and opaque borrowers, domestic banks are thought to have an advantage in using so-called 'soft information' in evaluating their creditworthiness. ${ }^{20}$ In contrast, unless foreign banks acquire local resources or expertise (for example by entering through mergers or acquisitions), they are generally thought to lack soft information and are, consequently, assumed to rely more heavily on 'hard information' contained in credit histories, collateral registries, and audited balance sheets and income statements. Given this assumption, theory predicts that foreign bank participation can be associated with reduced access to credit for informationally opaque firms (Detragiache et al., 2008 and Gormley, 2014). Moreover, these

\footnotetext{
${ }^{19}$ Micco and Panizza (2006), Bertay et al. (2015) and Duprey (2015) provide evidence on the countercyclical lending behavior of government-owned banks based on cross-country bank-level panel data, while results from Foos (2009) and Onder and Ozyldirim (2013) focus on the case of government-owned banks in Germany and Turkey, respectively.

${ }^{20}$ By soft information we mean knowledge of borrowers' intangible traits (character, competence, work ethic, and so forth) and hard to quantify local business conditions.
} 
studies also imply that, as foreign banks focus on lending to the largest and most profitable borrowers, their presence could be destabilizing for domestic banks causing overall credit levels, or at least credit access for some market segments, to be reduced.

There is in fact cross-country empirical evidence indicating that foreign bank presence is negatively associated with private credit to GDP and private credit growth rates in low-income countries where information barriers are more severe (Detragiache et al., 2008; Claessens and Van Horen, 2014). Per capita income levels have also been shown to be strongly associated with broad measures of the quality of institutions (Knack and Keefer, 1995), which could in part explain why foreign banks might find it more difficult to lend in low income countries. In fact, there is direct evidence that the negative association between private credit and foreign bank presence is found in countries where contract enforcement is costlier and access to credit information is limited (Claessens and Van Horen, 2014). Relatedly, Beck et al. (2011) finds that the prevalence, pricing, and conditions on SME loans is tied to cross-country differences in the institutional and legal environment.

The context surrounding the entry of foreign banks is also likely to affect the relationship between their presence and credit levels. For example, Cull and Martinez Peria (2008) shows that the negative relation between foreign bank presence and credit levels is driven by the nonrandom entry of foreign banks into banking markets that were in crisis or experienced large drops in credit levels prior to their entry. ${ }^{21}$

At the same time, evidence consistent with the notion that foreign-owned banks lend to larger, less informationally opaque borrowers has been found in a number of countries and

\footnotetext{
${ }^{21}$ Foreign banks often were brought in to acquire failed domestic banks and thus re-capitalize banking sectors in the period that those authors study. Ridding the balance sheets of the non-performing assets of those target banks likely contributed to lower overall credit levels, but this could hardly be blamed on the foreign acquirers.
} 
regions including Argentina (Berger et al., 2001), Mexico (Beck and Martinez Peria, 2010), Pakistan (Mian 2003, 2006), India (Berger et al. 2008; Gormley, 2010), and Central and Eastern Europe (Beck and Brown, 2015). ${ }^{22}$ Yet, as argued by Berger and Udell (2006) lending to small businesses need not be predicated on soft information gained through local knowledge and relationships. Rather, improvements to the legal and regulatory environment can facilitate lending to small businesses using different lending technologies.

There is indeed evidence that despite potential disadvantages in relationship lending, foreign banks are developing new business models, new technologies, and risk management systems that facilitate arms-length lending to small firms (De la Torre et al., 2010). These include credit scoring, standardized risk-rating tools and processes, and special products such as asset-based lending, factoring, fixed-asset lending, and leasing. Consistent with that conjecture, Clarke et al. (2005b) finds that large foreign banks, which are potentially more likely to adopt these business models than smaller ones, lent as much or more to SMEs as large domestic banks in four Latin American countries (Argentina, Chile, Colombia, and Peru). Using detailed credit registry data from Bolivia on the terms and pricing of loans, Beck et al. (forthcoming) provides further evidence in support of the Berger and Udell conjectures, showing that foreign banks are able to serve the same clientele as domestic banks by requiring collateral, imposing shorter maturities on loans, and basing their pricing on credit ratings and collateral pledges.

It is also possible that competition from foreign banks for large, informationally transparent borrowers leads some domestic banks to go down-market, increasing their lending to informationally opaque borrowers. Clarke et al. (2006) provides evidence for a sample of firms from developing and transition countries that foreign bank participation was associated with

\footnotetext{
${ }^{22}$ Similar evidence has been provided in the context of interstate banking deregulation in the United States (e.g. Keeton, 1996).
} 
improved financing conditions for all firms, but the effects were most pronounced for larger firms. Similarly, in Eastern Europe, foreign bank presence was not associated with reductions in access to credit for SMEs, ${ }^{23}$ though foreign banks tended to lend more to larger, often multinational, businesses than domestic banks (De Haas et al., 2010; Giannetti and Ongena, 2012) and many SMEs were incorrectly anticipating that their loan application would be rejected by foreign banks (Brown et al., 2011).

Much of the evidence on how host country banking volatility shapes foreign banks' role in credit provision was covered in the previous section, and so we will not revisit it here. Instead, we focus on papers that assess the adaptability of alternative lending approaches over the business cycle. From a theoretical perspective, Bolton et al. (2016) shows how banks that focus on relationship lending are better able to relax credit constraints during economic downturns than banks that rely on hard information lending approaches. They do so by charging higher intermediation spreads than other banks in normal times, which enables them to lend on more favorable terms during crisis times. ${ }^{24}$ Using information on banks' lending techniques from face-to-face interviews with the CEOs of 400 banks across 21 countries in Eastern Europe and the Caucasus, Beck et al. (2014) confirms that firms located in areas with more relationship lenders faced less severe financial constraints than others during the crisis (2008), but not during the credit boom (2005). Even within individual countries, they find that relationship lending helped ease credit constraints to a greater extent in regions that experienced sharper economic downturns during the crisis. They also find that relationship lending was especially effective in

\footnotetext{
${ }^{23}$ Consistently with these findings, several papers have documented that bank integration in the United States generated competitive pressures which increased access to credit for all firms, including for the less transparent ones (e.g., Black and Strahan, 2002; Cetorelli and Strahan, 2006; Kerr and Nanda, 2009; Rice and Strahan, 2010).

${ }^{24}$ Bolton et al. (2016) confirms the theoretical predictions using data from the Italian credit registry during the global financial crisis.
} 
easing financial constraints faced by young, small, non-exporters that lacked tangible assets and had no other sources of external finance than bank lending during the crisis.

However, those interviews also reveal that in this region at least, the traditional depiction of foreign-owned banks as transaction lenders (relying on hard verifiable financial information and pledged assets in lending decisions) and domestic banks as relationship lenders did not hold. There were relationship and transaction lenders among both types of bank owners. This could reflect the fact that foreign banks pursue different strategies, and have different levels of commitment, within the same host countries. For example, Bonin and Louie (forthcoming) finds that the 'Big Six' multinational European banks operating in a number of Eastern European countries maintained lending growth rates comparable to those of domestic banks during recent crisis periods. In contrast, the loan growth of the non-'Big Six' foreign banks exceeded that of domestic banks (and of 'Big Six' foreign banks) prior to the global crisis, but declined relative to that of other banks during the crisis period. They view that evidence as consistent with 'Big Six' banks treating these host countries as something akin to a second home market.

\section{The evidence on government bank ownership}

Credit market failures have long provided a key rationale for government-owned banks. Information asymmetries and/or weaknesses in the contracting environment make it less likely that private banks will serve some market segments such as small, informationally opaque borrowers. In principle, government-owned banks could step in to provide credit to disadvantaged (but creditworthy) borrowers, thus resolving market failures and expanding access to credit. In practice, however, the record of state banks in credit provision to the underserved has not been a strong one. Cross country evidence indicates that a higher share of government 
ownership in banking is negatively associated with the presence of bank branches and ATMs, and not significantly linked to indicators of the prevalence of loans and deposit accounts (Beck et al., 2007). Moreover, proxies for barriers to access and use of banking services are also increasing with the level of government ownership in banking (and, conversely, decreasing with foreign bank participation levels). Finally, the negative effects of bank concentration on widespread access to credit have been shown to be more pronounced in countries with higher shares of state bank ownership (Beck et al., 2004).

In large part, the inability of government-owned banks to foster deeper access to financial services (particularly credit) stems from political influences on their lending decisions, as noted in section 4.2. ${ }^{25}$ For example, Sapienza (2004) finds that government-owned banks in Italy charge lower interest rates to otherwise similar (or even the same) borrowers and lend more to politically affiliated firms in election years. In India, Berger et al. (2008) finds that governmentowned banks are more likely to maintain lending relationships with government-owned and rural firms, rather than the smaller, informationally opaque firms that many state banks are ostensibly designed to serve. Similarly, in China, the country with perhaps the highest level of state involvement in banking, government-owned firms have long received credit disproportionately to their profitability, as have individuals with affiliation to the Communist Party (see Cull et al., 2015, for a review of the literature).

At the same time, government-owned banks may have an important role to play in stabilizing credit flows during crises. Theoretical models suggest that state banks are better able

\footnotetext{
${ }^{25}$ Private banks can also exert political influence. They can oppose the entry of new competitors, thus impeding financial development and access to finance (Kroszner and Strahan, 1999; Rajan and Zingales, 2003; Perotti and Volpin, 2007). They engage with depositors/debtors and the government in a "game of banks bargain" which also governs the pricing of credit and its terms, and the allocation of losses in case of a bank failure (Calomiris and Haber, 2014).
} 
to provide loans to the real sector during crises, while private banks cut back lending and increase liquidity holdings (Brei and Schclarek, 2015). This is because state banks are assumed not to have pure incentives to maximize profits given risks, and are less likely to suffer withdrawals of deposits and bank runs because of the greater likelihood that they will be recapitalized than private banks. Bertay et al. (2015) provides empirical evidence consistent with those predictions, finding that lending by state banks is substantially less pro-cyclical than lending by private banks in countries with good governance (which could help negate political influence on lending decisions). State banks also expand their non-deposit liabilities more slowly than private banks during downturns and report more stable non-performing loan ratios over the business cycle. In short, the recent evidence is consistent with the notion that, at least in countries with good governance, state banks may be effective in stabilizing credit flows during crises.

\section{Conclusions}

Since the mid-1990s, banking sectors around the world have experienced a significant transformation in terms of ownership structure: foreign bank participation has increased while, until the recent GFC, the presence of government-owned banks declined across most regions. This paper described in detail the changes and recent patterns in bank ownership around the world and summarized the empirical evidence on the impact of these changes for bank performance, competition, stability, and access to finance.

The evidence indicates that foreign-owned banks tend to be more efficient than domestic banks in developing countries, typically promote competition in host country banking sectors, and help stabilize credit when host countries face idiosyncratic shocks. But, as highlighted in 
recent research since the GFC, there are trade-offs since foreign-owned banks can also transmit external shocks. In addition, they might not always contribute to expanded access to credit. But context matters. Access to credit increases with the level of competition in the banking sector when foreign banks entered and with a country's level of institutional development. And the negative relation between foreign bank presence and credit levels found in some papers could stem, in part, from the fact that foreign banks were brought in to recapitalize failing banking sectors.

Overall, there is little evidence that government bank ownership provides substantial benefits (relative to other types of ownership) to the banking sector, the real economy, or users of banking services, especially in developing countries. While there is some recent evidence that government-owned banks can help stabilize credit growth during crises, in general, they have had a negative impact on competition and banking performance and their record in expanding access to credit is, at best, mixed. 


\section{References}

Aiyar, S. (2012). From financial crisis to great recession: The role of globalized banks. The American Economic Review 102(3), 225-230.

Allen, F., Jackowicz, K., Kowalewski, O., \& Kozłowski, L. (2017). Bank lending, crises, and changing ownership structure in Central and Eastern European countries. Journal of Corporate Finance 42, 494-515.

Altunbas, Y., Evans, L., \& Molyneux, P. (2001). Bank ownership and efficiency. Journal of Money, Credit and Banking 33(4), 926-954.

Anginer, D., Cerutti, E., \& Pería, M. S. M. (2017). Foreign bank subsidiaries' default risk during the global crisis: what factors help insulate affiliates from their parents? Journal of Financial Intermediation 29, 19-30, 2017.

Arena, M., Reinhart C., \& Vazquez F. (2007). The lending channel in Emerging economics: Are foreign banks different? IMF Working Paper, 07/48.

Ashcraft, A. (2006). New evidence on the lending channel. Journal of Money, Credit and Banking, 38, 751-75.

Atkinson, A. B. and J. E. Stiglitz (1980). Lectures on Public Economics, London, Mc-Graw Hill.

Balmaceda, F., Fischer, R. D., \& Ramirez, F. (2014). Financial liberalization, market structure and credit penetration. Journal of Financial Intermediation 23(1), 47-75.

Banerjee, A. V. (1997). A theory of misgovernance. The Quarterly Journal of Economics 112(4), 1289-1332.

Barajas, A., Steiner, R., \& Salazar, N. (2000). The impact of liberalization and foreign investment in Colombia's financial sector. Journal of development economics 63(1), 157-196.

Barth, J. R., Caprio Jr, G., \& Levine, R. (2001). Banking systems around the globe: Do regulation and ownership affect performance and stability? In Prudential supervision: What works and what doesn't (pp. 31-96). University of Chicago Press.

Barth, J. R., Caprio, G., \& Levine, R. (2004). Bank regulation and supervision: what works best? Journal of Financial intermediation 13(2), 205-248.

Bayraktar, N., \& Wang, Y. (2004). Foreign bank entry, performance of domestic banks, and sequence of financial liberalization. World Bank Policy Research Working Paper, 3416.

Beck, T., \& Brown, M. (2015). Foreign bank ownership and household credit. Journal of Financial Intermediation 24(4), 466-486. 
Beck, T., Cull, R., \& Jerome, A. (2005). Bank privatization and performance: Empirical evidence from Nigeria. Journal of Banking \& Finance 29(8), 2355-2379.

Beck, T., Degryse, H., De Haas, R., \& Van Horen, N. (2014). When arm's length is too far. Relationship banking over the business cycle. EBRD working paper no. 169.

Beck, T., Demirgüç-Kunt, A., \& Martinez Peria, M. S. (2007). Reaching out: Access to and use of banking services across countries. Journal of Financial Economics 85(1), 234-266.

Beck, T., Demirgüç-Kunt, A., \& Martinez Pería, M. S. (2011). Bank financing for SMEs: Evidence across countries and bank ownership types. Journal of Financial Services Research 39(1-2), 35-54.

Beck, T., Fuchs, M., Singer, D., \& Witte, M. (2014). Making cross-border banking work for Africa. Deutsche GIZ, Bonn and Eschborn.

Beck, T., Ioannidou, v.,\& Schafer, L. (Forthcoming). Foreigners vs. natives: Bank lending technologies and loan pricing. Management Science.

Beck, T., \& Martinez Peria, M. S. (2010). Foreign bank participation and outreach: Evidence from Mexico. Journal of Financial Intermediation 19(1), 52-73.

Behn, M. Haselmann R., Seru, A., \& Vig, V. (2014). Does financial structure shape industry structure? Evidence from timing of bank liberalization. London Business School, mimeo.

Berger, A. N., Clarke, G. R., Cull, R., Klapper, L., \& Udell, G. F. (2005). Corporate governance and bank performance: A joint analysis of the static, selection, and dynamic effects of domestic, foreign, and state ownership. Journal of Banking \& Finance 29(8), 2179-2221.

Berger, A. N., DeYoung, R., Genay, H., \& Udell, G. F. (2000). Globalization of financial institutions: Evidence from cross-border banking performance. Brookings-Wharton papers on financial services 2000(1), 23-120.

Berger, A. N., Hasan, I., \& Zhou, M. (2009). Bank ownership and efficiency in China: What will happen in the world's largest nation? Journal of Banking \& Finance 33(1), 113-130.

Berger, A. N., Klapper, L. F., Martinez Peria, M. S., \& Zaidi, R. (2008). Bank ownership type and banking relationships. Journal of Financial Intermediation 17(1), 37-62.

Berger, A. N., Klapper, L. F., \& Udell, G. F. (2001). The ability of banks to lend to informationally opaque small businesses. Journal of Banking \& Finance 25(12), 2127-2167.

Bertay, A. C., Demirgüç-Kunt, A., \& Huizinga, H. (2015). Bank ownership and credit over the business cycle: Is lending by state banks less procyclical? Journal of Banking \& Finance 50, 326-339.

Berger, A. N., \& Udell, G. F. (2006). A more complete conceptual framework for SME finance. Journal of Banking \& Finance 30(11), 2945-2966. 
Bhattacharyya, A., Lovell, C. K., \& Sahay, P. (1997). The impact of liberalization on the productive efficiency of Indian commercial banks. European Journal of operational research 98(2), 332-345.

Black, S. E., \& Strahan, P. E. (2002). Entrepreneurship and bank credit availability. The Journal of Finance 57(6), 2807-2833.

Bolton, P., Freixas, X., \& Gambacorta, L. (2016). Relationship and transaction lending in a crisis. Review of Financial Studies 29(10), 2643-2676.

Bonaccordi di Patti, E., \& Hardy, D. C. (2005). Financial sector liberalization, bank privatization, and efficiency: Evidence from Pakistan. Journal of Banking \& Finance 29(8), 2381-2406.

Bonin, J. P., Hasan, I., \& Wachtel, P. (2005a). Privatization matters: Bank efficiency in transition countries. Journal of Banking \& Finance 29(8), 2155-2178.

Bonin, J. P., Hasan, I., \& Wachtel, P. (2005b). Bank performance, efficiency and ownership in transition countries. Journal of banking \& finance 29(1), 31-53.

Bonin, J. \& Louie, D. (Forthcoming). Did foreign banks stay committed to emerging Europe during recent financial crises? Journal of Comparative Economics.

Boubakri, N., Cosset, J. C., Fischer, K., \& Guedhami, O. (2005). Privatization and bank performance in developing countries. Journal of Banking \& Finance 29(8), 2015-2041.

Brei, M., \& Schclarek, A. (2013). Public bank lending in times of crisis. Journal of Financial Stability 9(4), 820-830.

Brei, M., \& Schclarek, A. (2015). A theoretical model of bank lending: Does ownership matter in times of crisis? Journal of Banking \& Finance 50, 298-307.

Brown, M., Ongena, S., Popov, A., \& Yeşin, P. (2011). Who needs credit and who gets credit in Eastern Europe? Economic Policy 26(65), 93-130.

Calomiris, C. W., \& Haber, S. H. (2014). Fragile by design: The political origins of banking crises and scarce credit. Princeton University Press.

Campello, M. (2002). Internal capital markets in financial conglomerates: Evidence from small bank responses to monetary policy. The Journal of Finance 57(6), 2773-2805.

Caprio, G., \& Martinez Peria, M. S. (2002). Avoiding disaster: policies to reduce the risk of banking crises. Monetary policy and exchange rate regimes: Options for the Middle East, 193230.

Carvalho, D. (2014). The real effects of government-owned banks: Evidence from an emerging market. The Journal of Finance 69(2), 577-609. 
Cetorelli, N., \& Goldberg, L. S. (2012a). Follow the money: Quantifying domestic effects of foreign bank shocks in the great recession. The American Economic Review 102(3), 213-218.

Cetorelli, N., \& Goldberg, L. S. (2012b). Liquidity management of US global banks: Internal capital markets in the great recession. Journal of International Economics 88(2), 299-311.

Cetorelli, N., \& Goldberg, L. S. (2012c). Banking globalization and monetary transmission. The Journal of Finance 67(5), 1811-1843.

Cetorelli, N., \& Strahan, P. E. (2006). Finance as a barrier to entry: Bank competition and industry structure in local US markets. The Journal of Finance 61(1), 437-461.

Chang, C., Hasan, I., \& Hunter, W. C. (1998). Efficiency of multinational banks: an empirical investigation. Applied Financial Economics 8(6), 689-696.

Chakravarty, S. P., \& Williams, J. M. (2006). How significant is the alleged unfair advantage enjoyed by state-owned banks in Germany? Cambridge Journal of Economics 30(2), 219-226.

Chantapong, S. (2005). Comparative study of domestic and foreign bank performance in Thailand: The regression analysis. Economic Change and Restructuring 38(1), 63-83.

Chava, S., \& Purnanandam, A. (2011). The effect of banking crisis on bank-dependent borrowers. Journal of Financial Economics 99(1), 116-135.

Chen, Y. S., Chen, Y., Hasan, I., \& Lin, C. Y. (2016). Is there a bright side of government banks? Evidence from the global financial crisis. Journal of Financial Stability 26(5), 128-143.

Chen, Z., Li, D., \& Moshirian, F. (2005). China's financial services industry: The intra-industry effects of privatization of the Bank of China Hong Kong. Journal of Banking \& Finance 29(8), 2291-2324.

Choi, M. J., Gutierrez, E., \& Martinez Peria, M. S. (2016). Dissecting foreign bank lending behavior during the 2008-2009 crisis. Financial Markets, Institutions \& Instruments 25(5), 361398

Claessens, S., Demirgüç-Kunt, A., \& Huizinga, H. (2001). How does foreign entry affect domestic banking markets? Journal of Banking \& Finance 25(5), 891-911.

Claessens, S., \& Laeven, L. (2004). What drives bank competition? Some international evidence. Journal of Money, Credit, and Banking 36(3), 563-583.

Claessens, S., \& Lee, J. K. (2003). Foreign banks in low-income countries: Recent developments and impacts. Globalization and National Financial Systems, 109.

Claessens, S., \& Van Horen, N. (2012). Being a foreigner among domestic banks: Asset or liability? Journal of Banking \& Finance 36(5), 1276-1290. 
Claessens, S., \& Van Horen, N. (2014). Foreign banks: Trends and impact. Journal of Money, Credit and Banking 46(s1), 295-326.

Claessens, S., \& Van Horen, N. (2015). The impact of the global financial crisis on banking globalization. IMF Economic Review 63(4), 868-918.

Claeys, S., \& Hainz, C. (2014). Modes of foreign bank entry and effects on lending rates: Theory and evidence. Journal of Comparative Economics 42(1), 160-177.

Clarke, G. R., Cull, R., \& Martinez Peria, M. S. (2006). Foreign bank participation and access to credit across firms in developing countries. Journal of Comparative Economics 34(4), 774-795.

Clarke, G., Cull, R., Martinez Peria, M. S., \& Sánchez, S. M. (2005b). Bank lending to small businesses in Latin America: does bank origin matter? Journal of Money, Credit and Banking 37(1), 83-118.

Clarke, G. R., Cull, R., \& Shirley, M. M. (2005a). Bank privatization in developing countries: A summary of lessons and findings. Journal of Banking \& Finance 29(8), 1905-1930.

Cole, S. (2009a). Fixing market failures or fixing elections? Agricultural credit in India. American Economic Journal: Applied Economics 1(1), 219-250.

Cole, S. (2009b). Financial development, bank ownership, and growth: Or, does quantity imply quality? The Review of Economics and Statistics 91(1), 33-51.

Coleman, N., \& Feler, L. (2015). Bank ownership, lending, and local economic performance during the 2008-2009 financial crisis. Journal of Monetary Economics 71, 50-66.

Cornett, M. M., Guo, L., Khaksari, S., \& Tehranian, H. (2010). The impact of state ownership on performance differences in privately-owned versus state-owned banks: An international comparison. Journal of Financial Intermediation 19(1), 74-94.

Cortes, K., \& Strahan, P. (2014). Tracing out capital flows: How financially integrated banks respond to natural disasters. Federal Reserve Bank of Cleveland, Working Paper No. 14-12.

Crystal, J.S., Dages, G., \& Goldberg, L. (2001). Does Foreign Ownership Contribute to Sounder Banks? The Latin American Experience. R.E. Litan, P. Masson, M. Pomerleano (Eds.), Open Doors: Foreign Participation in Emerging Financial Systems, Brookings Press, Washington.

Crystal, J. S., Dages, B. G., \& Goldberg, L. S. (2002). Has foreign bank entry led to sounder banks in Latin America? Current Issues in Economics and Finance 8(1), 1-6.

Cull, R., Li, W., Sun, B., \& L.C. Xu. (2015). Government connections and financial constraints: Evidence from a large sample of Chinese firms. Journal of Corporate Finance 32, 271-294.

Cull, R., \& Martinez Peria, M. S. (2013). Bank ownership and lending patterns during the 20082009 financial crisis: evidence from Latin America and Eastern Europe. Journal of Banking \& Finance 37(12), 4861-4878. 
Dages, B. G., Goldberg, L. \& Kinney, D. (2000). Foreign and domestic bank participation in emerging markets: Lessons from Mexico and Argentina. National Bureau of Economic Research, Working Paper 7714.

De Haas, R., Ferreira, D., \& Taci, A. (2010). What determines the composition of banks' loan portfolios? Evidence from transition countries. Journal of Banking \& Finance 34(2), 388-398.

De Haas, R., Korniyenko, Y., Pivovarsky, A., \& Tsankova, T. (2015). Taming the herd? Foreign banks, the Vienna Initiative and crisis transmission. Journal of Financial Intermediation 24(3), 325-355.

De Haas, R., \& Van Lelyveld, I. (2006). Foreign banks and credit stability in Central and Eastern Europe. A panel data analysis. Journal of banking \& Finance 30(7), 1927-1952.

De Haas, R., \& Van Lelyveld, I. (2010). Internal capital markets and lending by multinational bank subsidiaries. Journal of Financial Intermediation 19(1), 1-25.

De Haas, R., \& Van Lelyveld, I. (2014). Multinational banks and the global financial crisis: Weathering the perfect storm? Journal of Money, Credit and Banking 46(1), 333-364.

De la Torre, A., Pería, M. S. M., \& Schmukler, S. L. (2010). Bank involvement with SMEs: Beyond relationship lending. Journal of Banking \& Finance 34(9), 2280-2293.

Degryse, H., Havrylchyk, O., Jurzyk, E., \& Kozak, S. (2012). Foreign bank entry, credit allocation and lending rates in emerging markets: Empirical evidence from Poland. Journal of Banking \& Finance 36(11), 2949-2959.

Delis, M. D., Kokas, S., \& Ongena, S. (2016). Foreign ownership and market power in banking: Evidence from a world sample. Journal of Money, Credit and Banking 48, 449-483.

Demirgüç-Kunt, A., \& Huizinga, H. (1999). Determinants of commercial bank interest margins and profitability: some international evidence. The World Bank Economic Review 13(2), 379408.

Demirgüç-Kunt, A., Levine, R. \& Min, H. (1998). Opening to foreign banks: issues of stability, efficiency, and growth. In Proceedings of the Bank of Korea Conference on the Implications of Globalization of World Financial Markets.

Detragiache, E., \& Gupta, P. (2006). Foreign banks in emerging market crises: Evidence from Malaysia. Journal of Financial Stability 2(3), 217-242.

Detragiache, E., Tressel, T., \& Gupta, P. (2008). Foreign banks in poor countries: theory and evidence. The Journal of Finance 63(5), 2123-2160.

DeYoung, R., \& Nolle, D. E. (1996). Foreign-owned banks in the United States: Earning market share or buying it? Journal of Money, Credit and Banking 28(4), 622-636. 
Duprey, T. (2015). Do publicly owned banks lend against the wind? International Journal of Central Banking 11(2), 65-112.

Epstein, R.A. (2008). In Pursuit of Liberalism: International Institutions in Postcomunist Europe, Baltimore, MD: John Hopkins University Press.

Epstein R.A. (2014). Assets or liabilities? The politics of bank ownership. Review of International Political Economy 21(4), 765-789.

Farazi, S., Feyen, E., \& Rocha, R. (2013). Bank ownership and performance in the Middle East and North Africa Region. Review of Middle East Economics and Finance 9(2), 159-196.

Foos, D. (2009). Lending conditions, macroeconomic fluctuations, and the impact of bank ownership. University of Mannheim, Department of Banking and Finance, manuscript.

Fries, S., \& Taci, A. (2005). Cost efficiency of banks in transition: Evidence from 289 banks in 15 post-communist countries. Journal of Banking \& Finance 29(1), 55-81.

Fungáčová, Z., Herrala, R., \& Weill, L. (2013). The influence of bank ownership on credit supply: Evidence from the recent financial crisis. Emerging markets review 15, 136-147.

Gelos, R. G., \& Roldós, J. (2004). Consolidation and market structure in emerging market banking systems. Emerging Markets Review 5(1), 39-59.

Gerschenkron, A. (1962). Economic backwardness in historical perspective: a book of essays (No. HC335 G386). Cambridge, MA: Belknap Press of Harvard University Press.

Giannetti, M., \& Ongena, S. (2012). Lending by example: Direct and indirect effects of foreign banks in emerging markets. Journal of International Economics 86(1), 167-180.

Gilje, E. P., Loutskina, E., \& Strahan, P. E. (2016). Exporting liquidity: Branch banking and financial integration. The Journal of Finance 71(3), 1159-1184.

Goetz, M. R., \& Gozzi, J. C. (2014). Financial integration and the co-movement of economic activity: Evidence from US States. Mimeo.

Goldberg, L. S. (2004). Financial-sector foreign direct investment and host countries: New and old lessons. FRB of New York Staff Report, (183).

Gormley, T. A. (2010). The impact of foreign bank entry in emerging markets: Evidence from India. Journal of Financial Intermediation 19(1), 26-51.

Gormley, T. A. (2014). Costly information, entry, and credit access. Journal of Economic Theory 154, 633-667.

Green, C., Murinde, V., \& Nikolov, I. (2004a). Are foreign banks in Central and Eastern Europe more efficient than domestic banks? Financial Markets in Central and Eastern Europe: Stability and Efficiency, 206. 
Green, C. J., Murinde, V., \& Nikolov, I. (2004b). The efficiency of foreign and domestic banks in Central and Eastern Europe: evidence on economies of scale and scope. Journal of Emerging Market Finance 3(2), 175-205.

Grigorian, D. A., \& Manole, V. (2006). Determinants of commercial bank performance in transition: an application of data envelopment analysis. Comparative Economic Studies 48(3), 497-522.

Haber, S. (2005). Mexico's experiment with bank privatization and liberalization 1991-2003. Journal of Banking and Finance 29, 2325-2353.

Hale, G., Kapan, T., \& Minoiu, C. (2016). Crisis transmission in the global banking network. IMF Working Paper, 16/91.

Hart, O. D., Shleifer, A. \& Vishny, R. (1997). The proper scope of government: Theory and application to prisons. Quarterly Journal of Economics 112, 1127-1162.

Hasan, I., \& Hunter, W. C. (1996). Efficiency of Japanese multinational banks in the United States. Research in Finance 14, 157-174.

Hasan, I., \& Marton, K. (2003). Development and efficiency of the banking sector in a transitional economy: Hungarian experience. Journal of Banking \& Finance 27(12), 2249-2271.

Havrylchyk, O. (2006). Efficiency of the Polish banking industry: Foreign versus domestic banks. Journal of Banking \& Finance 30(7), 1975-1996.

Havrylchyk, O. \& Jurzyk, P. E. (2011). Profitability of foreign and domestic banks in Central and Eastern Europe: Does the mode of entry matter? Economics of Transition 19 (2011), 443472.

Huang, R. (2008). The Effect of Monetary Tightening on Local Banks. FRB of Philadelphia, Working Paper No. 08-20.

Iannotta, G., Nocera, G., \& Sironi, A. (2007). Ownership structure, risk and performance in the European banking industry. Journal of Banking \& Finance 31(7), 2127-2149.

Imai, M., \& Takarabe, S. (2011). Bank integration and transmission of financial shocks: Evidence from Japan. American Economic Journal: Macroeconomics 3(1), 155-183.

Inter-American Development Bank (2005). Unlocking Credit: The Quest for Deep and Stable Bank Lending. Economic and Social Progress Report 2005.

International Monetary Fund (2009). World Economic Outlook. IMF. Washington DC. April.

Isik, I., \& Hassan, M. K. (2002). Cost and profit efficiency of the Turkish banking industry: An empirical investigation. The Financial Review, 37(2), 257-279. 
Jemric, I., \& Vujcic, B. (2002). Efficiency of banks in Croatia: A DEA approach. Comparative Economic Studies 44(2-3), 169-193.

Jeon, B. N., Olivero, M. P., \& Wu, J. (2011). Do foreign banks increase competition? Evidence from emerging Asian and Latin American banking markets. Journal of Banking \& Finance 35(4), 856-875.

Jeon, B. N., Olivero, M. P., \& Wu, J. (2013). Multinational banking and the international transmission of financial shocks: Evidence from foreign bank subsidiaries. Journal of Banking \& Finance 37(3), 952-972.

Kaas, L. (2004). Financial market integration and loan competition: when is entry deregulation socially beneficial? European Central Bank, Working Paper No. 403

Keeton, W. R. (1996). Do bank mergers reduce lending to businesses and farmers? New evidence from tenth district states. Economic Review-Federal Reserve Bank of Kansas City, 81(3), 63.

Kerr, W. R., \& Nanda, R. (2009). Democratizing entry: Banking deregulations, financing constraints, and entrepreneurship. Journal of Financial Economics 94(1), 124-149.

Khwaja, A. I., \& Mian, A. (2005). Do lenders favor politically connected firms? Rent provision in an emerging financial market. The Quarterly Journal of Economics, 1371-1411.

Klapper, L., Martinez Peria, M. S., \& Zia, B. (2014). Banking in developing nations of Asia: changes in ownership structure and lending over the financial crisis. Oxford Handbook of Banking, 2nd Edition. Oxford, Oxford University Press.

Knack, S. \& Keefer, P. (1995). Institutions and economic performance: Cross-country test using alternative institutional measures. Economics and Politics 7(3), 207-227.

Kraft, E., Hofler, R., \& Payne, J. (2006). Privatization, foreign bank entry and bank efficiency in Croatia: a Fourier-flexible function stochastic cost frontier analysis. Applied Economics, 38(17), 2075-2088.

Krozner, P. \& Strahan R. (1999). What drives deregulation? Economics and politics of the relaxation of bank branching restrictions. Quarterly Journal of Economics 114, 1437-1467.

La Porta, R., Lopez-de-Silanes, F., \& Shleifer, A. (2002). Government ownership of banks. The Journal of Finance 57(1), 265-301.

Lane, P. R., \& Milesi-Ferretti, G. M. (2001). The external wealth of nations: measures of foreign assets and liabilities for industrial and developing countries. Journal of international Economics 55(2), 263-294.

Lane, P. R., \& Milesi-Ferretti, G. M. (2007). The external wealth of nations mark II: Revised and extended estimates of foreign assets and liabilities, 1970-2004. Journal of international Economics, 73(2), 223-250. 
Lehner, M., \& Schnitzer, M. (2008). Entry of foreign banks and their impact on host countries. Journal of Comparative Economics 36(3), 430-452.

Leony, L., \& Romeu, R. (2011). A model of bank lending in the global financial crisis and the case of Korea. Journal of Asian Economics, 22(4), 322-334.

Levine, Ross. "Foreign Banks, Financial Development, and Economic Growth." in International Financial Markets: Harmonization versus Competition, ed., Claude E. Barfield, Washington, D.C.: The AEI Press, 1996.

Levy-Yeyati, E., \& Micco, A. (2007). Concentration and foreign penetration in Latin American banking sectors: Impact on competition and risk. Journal of Banking \& Finance, 31(6), 16331647.

Levy-Yeyati, E., Micco, A., Panizza, U. (2007). A Reappraisal of State-Owned Banks. Economia $7(2), 209-259$.

Loutskina, E., \& Strahan, P. E. (2015). Financial integration, housing, and economic volatility. Journal of Financial Economics 115(1), 25-41.

Majnoni, G., \& Shankar, R. and Varhegyi E. (2003). The dynamics of foreign bank ownership: Evidence from Hungary. World Bank Publications.

Martinez-Diaz, L. (2009). Globalizing in Hard Times: The Politics of Banking-Sector Opening in the Emerging World, Ithaca, NY: Cornell University Press.

Matoušek, R., \& Taci, A. (2004). Efficiency in banking: Empirical evidence from the Czech Republic. Economics of Planning 37(3-4), 225-244.

Matthews, K., \& Ismail, M. (2006). Efficiency and productivity growth of domestic and foreign commercial banks in Malaysia (No. E2006/2). Cardiff University, Cardiff Business School, Economics Section.

Megginson, W. L. (2005). The economics of bank privatization. Journal of Banking \& Finance 29(8), 1931-1980.

Mian, A. (2003). Foreign, private domestic, and government banks: New evidence from emerging markets. Journal of Banking and Finance 27(7), 1219-1410.

Mian, A. (2006). Distance constraints: The limits of foreign lending in poor economies. The Journal of Finance 61(3), 1465-1505.

Micco, A., \& Panizza, U. (2006). Bank ownership and lending behavior. Economics Letters 93(2), 248-254.

Micco, A., Panizza, U., \& Yanez, M. (2007). Bank ownership and performance. Does politics matter? Journal of Banking \& Finance 31(1), 219-241. 
Mihaljek, D. (2011). How have external factors affected monetary policy in the EMEs? The influence of external factors on monetary policy frameworks and operations, BIS Papers 57, 1-9.

Miller, S. R., \& Parkhe, A. (2002). Is there a liability of foreignness in global banking? An empirical test of banks' X-efficiency. Strategic Management Journal 23(1), 55-75.

Morgan, D., Rime, B., \& Strahan, P. (2003). Bank integration and state business cycles. Quarterly Journal of Economics 119, 1555-84

Mulyaningsih, T., Daly, A., \& Miranti, R. (2015). Foreign participation and banking competition: Evidence from the Indonesian banking industry. Journal of Financial Stability 19, 70-82.

Obstfeld, M. and Taylor, A. M. (2004), Global Capital Markets Integration, Crisis, and Growth. Cambridge University Press 2004, Cambridge.

Önder, Z., \& Özyıldırım, S. (2013). Role of bank credit on local growth: Do politics and crisis matter? Journal of Financial Stability 9(1), 13-25.

Otchere, I. (2005). Do privatized banks in middle-and low-income countries perform better than rival banks? An intra-industry analysis of bank privatization. Journal of Banking \& Finance 29(8), 2067-2093.

Otchere, I., \& Chan, J. (2003). Intra-industry effects of bank privatization: A clinical analysis of the privatization of the Commonwealth Bank of Australia. Journal of Banking \& Finance 27(5), 949-975.

Panzar, J. C., \& Rosse, J. N. (1987). Testing for" monopoly" equilibrium. The Journal of Industrial Economics, 443-456.

Park, K., \& Pennacchi, G. (2009). Harming depositors and helping borrowers: The disparate impact of bank consolidation. Review of Financial Studies 22(1), 1-40.

Peek, J., \& Rosengren, E. S. (1997). The international transmission of financial shocks: The case of Japan. American Economic Review 87(4), 495-505.

Peek, J., \& Rosengren, E. S. (2000a). Implications of the globalization of the banking sector: The Latin American experience. In Conference Series-Federal Reserve Bank of Boston, Vol. 44, pp. 145-170.

Peek, J., \& Rosengren, E. S. (2000b). Collateral damage: Effects of the Japanese bank crisis on real activity in the United States. American Economic Review 90(1), 30-45.

Peek, J., Rosengren, E. S., \& Kasirye, F. (1999). The poor performance of foreign bank subsidiaries: were the problems acquired or created? Journal of Banking \& Finance 23(2), 579604. 
Perotti, E. (1994). A taxonomy of post-socialist financial systems: Decentralized enforcement and the creation of inside money. The Economics of Transition 2(1), 71-81.

Perotti, E. \& Volpin, P. (2007). Lobbying on Entry. CEPR Working Paper, 4519.

Perotti, E., \& Vorage, M. (2010). Bank ownership and financial stability. Tinbergen Institute Discussion Paper. TI 2010-022/2.

Popov, A., \& Udell, G. F. (2012). Cross-border banking, credit access, and the financial crisis. Journal of International Economics 87(1), 147-161.

Rajan, R. G., \& Zingales, L. (2003). The great reversals: the politics of financial development in the twentieth century. Journal of Financial Economics 69(1), 5-50.

Rice, T., \& Strahan, P. E. (2010). Does credit competition affect small-firm finance? The Journal of Finance 65(3), 861-889.

Sapienza, P. (2004). The effects of government ownership on bank lending. Journal of financial economics 72(2), 357-384.

Schnabl, P. (2012). The international transmission of bank liquidity shocks: Evidence from an emerging market. The Journal of Finance 67(3), 897-932.

Sensarma, R. (2006). Are foreign banks always the best? Comparison of state-owned, private and foreign banks in India. Economic Modelling 23(4), 717-735.

Shleifer, A. (1998). State versus private ownership, Journal of Economic Perspectives 12, $133-150$.

Shleifer, A., \& Vishny, R. W. (1994). Politicians and firms. The Quarterly Journal of Economics 109(4), 995-1025.

Stein, H. (2010). Financial liberalization, institutional transformation and credit allocation in developing countries: The World Bank and the internationalization of banking, Cambridge Journal of Economics 34, 257-73.

Stiglitz, J. E. (1993). The role of the state in financial markets. The World Bank Economic Review 7(suppl 1), 19-52.

Van Tassel, E., \& Vishwasrao, S. (2007). Asymmetric information and the mode of entry in foreign credit markets. Journal of Banking \& Finance 31(12), 3742-3760.

Weill, L. (2003). Banking efficiency in transition economies. Economics of transition 11(3), 569-592.

Williams, J., \& Nguyen, N. (2005). Financial liberalization, crisis, and restructuring: A comparative study of bank performance and bank governance in South East Asia. Journal of Banking \& Finance 29(8), 2119-2154. 
Wu, H. L., Chen, C. H., \& Lin, M. H. (2007). The effect of foreign bank entry on the operational performance of commercial banks in the Chinese transitional economy. Post-Communist Economies 19(3), 343-357.

Yildirim, S. H., \& Philippatos, G. C. (2007). Efficiency of banks: recent evidence from the transition economies of Europe, 1993-2000. European Journal of Finance 13(2), 123-143. 
Figure 1.1. Share of assets owned by foreign banks, 2012-2013

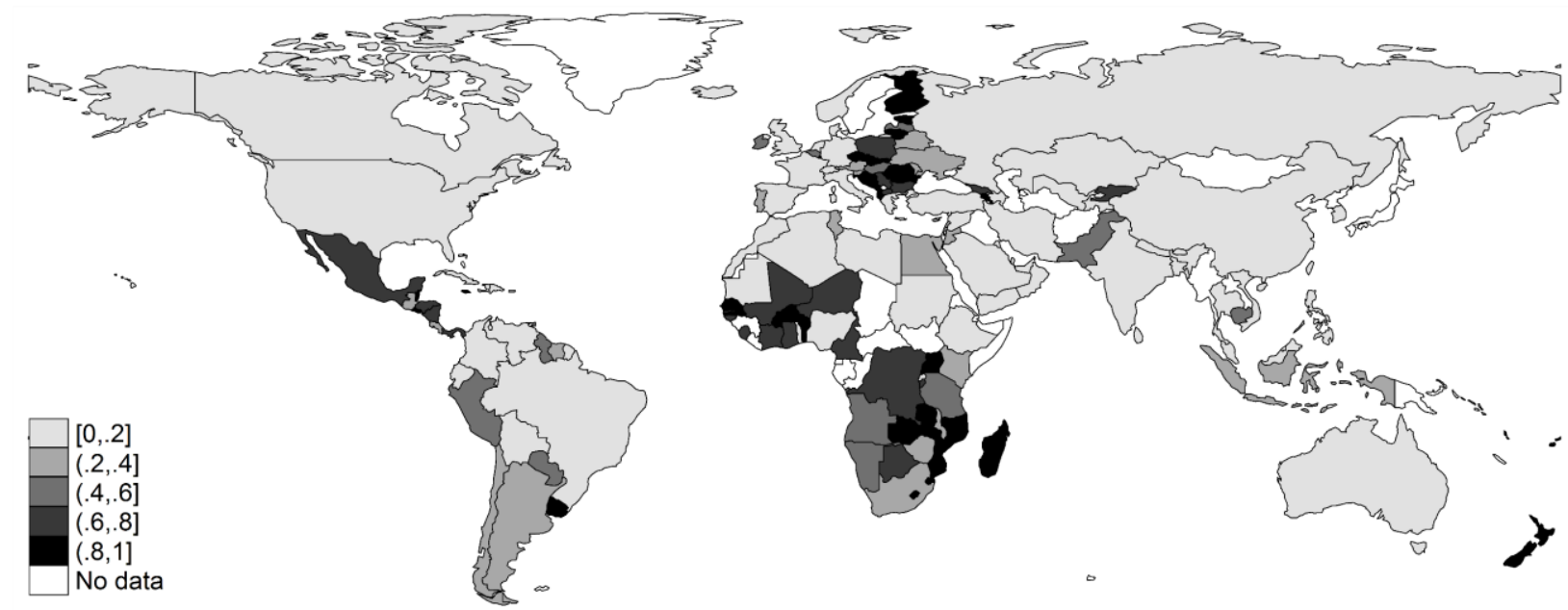

Notes: The map reflects the most recent data available in the cited sources. 2012-2013 data are available for $80 \%$ of the sample.

Sources: Claessens and Van Horen (2015); Bank Regulation and Supervision surveys (World Bank).

Figure 1.2. Share of assets owned by government banks, 2010

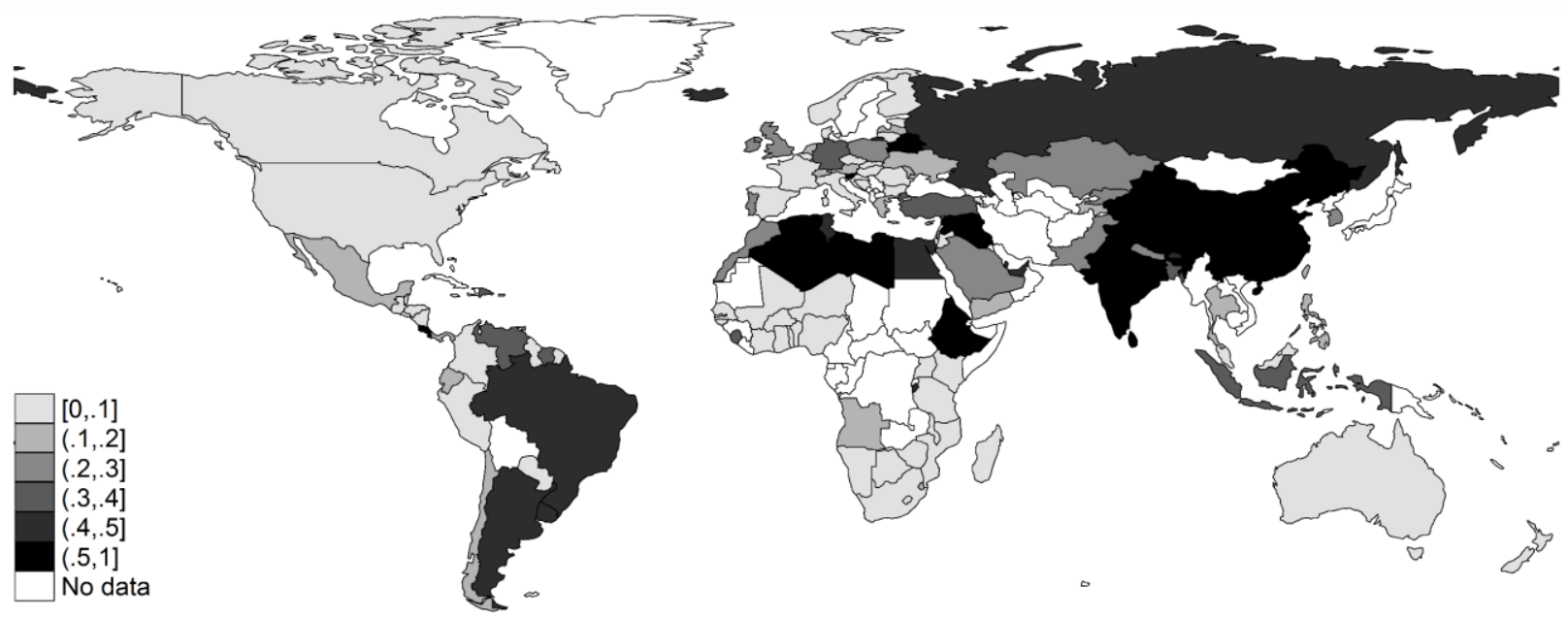

Notes: The map reflects 2010 data, except for the MENA region where 2008 figures are used instead.

Sources: Bank Regulation and Supervision surveys (World Bank); Farazi et al. (2013); Cull and Martinez Peria (2012); China Banking Regulatory Commission; Beck et al. (2014). 
Figure 2.1. Asset share of foreign-owned banks by income group, 1995-2013

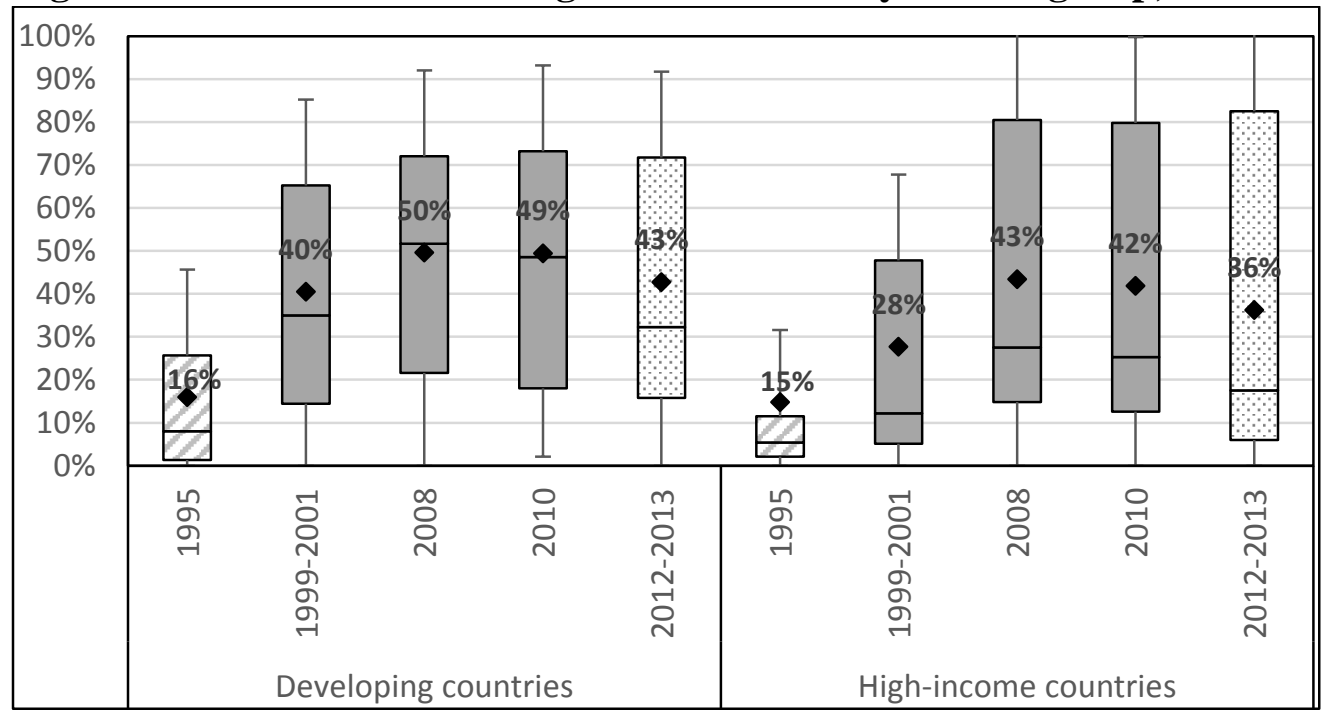

Note: The statistics are computed over country aggregates. The boxplots show the minimum, 25th percentile, median, 75th percentile and maximum, and the diamonds represent the average. Estimates for 1999-2010 are based on a balanced sample of 65 developing and 28 high income countries, while estimates for 1995 and 2012-2013 are based on a smaller sample of countries (cf list of countries in Table A.1 in Appendix). Ownership is defined as the asset share of banks that are more than $50 \%$ controlled by the foreign owners, except for 1995 where ownership reflects the actual share owned by foreign banks.

Sources: Micco et al. (2007) for 1995; Bank regulation and Supervision Surveys for 1999-2010; Claessens and Van Horen (2015) for 2012-2013.

Figure 2.2. Asset share of government-owned banks by income group, 1995-2010

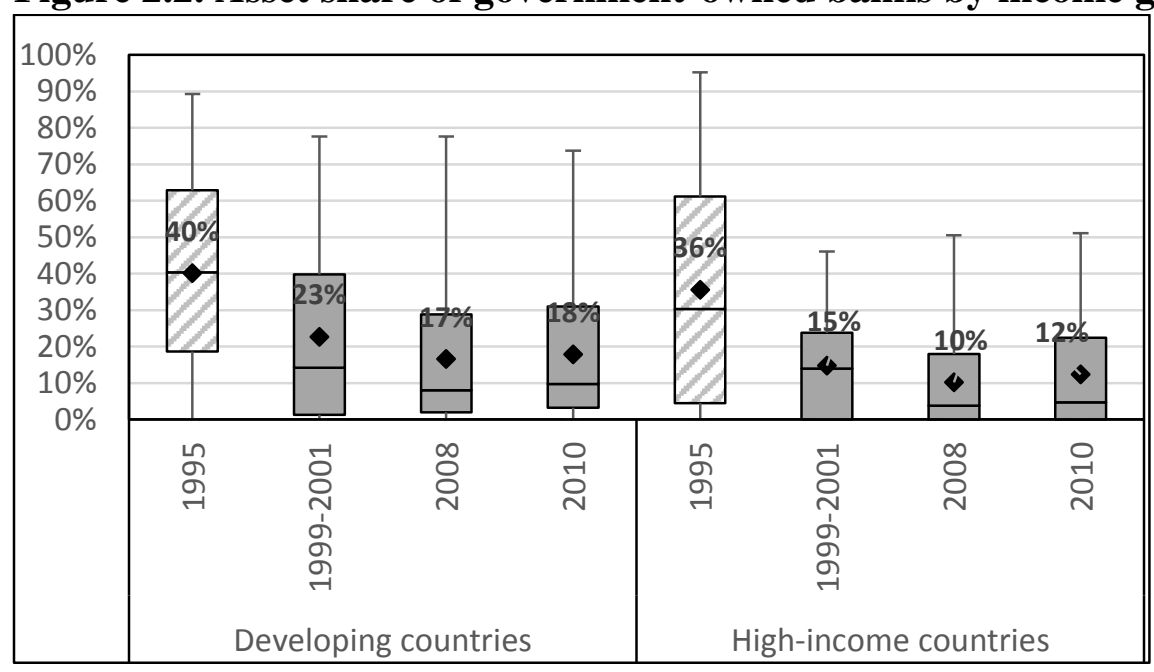

Note: The statistics are computed over country aggregates. The boxplots show the minimum, 25th percentile, median, 75th percentile and maximum, and the diamonds represent the average. Estimates for 1999-2010 are based on a balanced sample of 65 developing and 28 high income countries, while estimates for 1995 are based on a smaller sample of countries (cf list of countries in Table A.1 in Appendix). Ownership is defined as the asset share of banks that are more than $50 \%$ controlled by the government, except for 1995 where ownership reflects the actual share owned by the government.

Sources: Micco et al. (2007) for 1995 and Bank regulation and Supervision Surveys for 1999-2010. 
Figure 3.1. Median asset share of foreign-owned banks in developing countries by region, 1995-2013

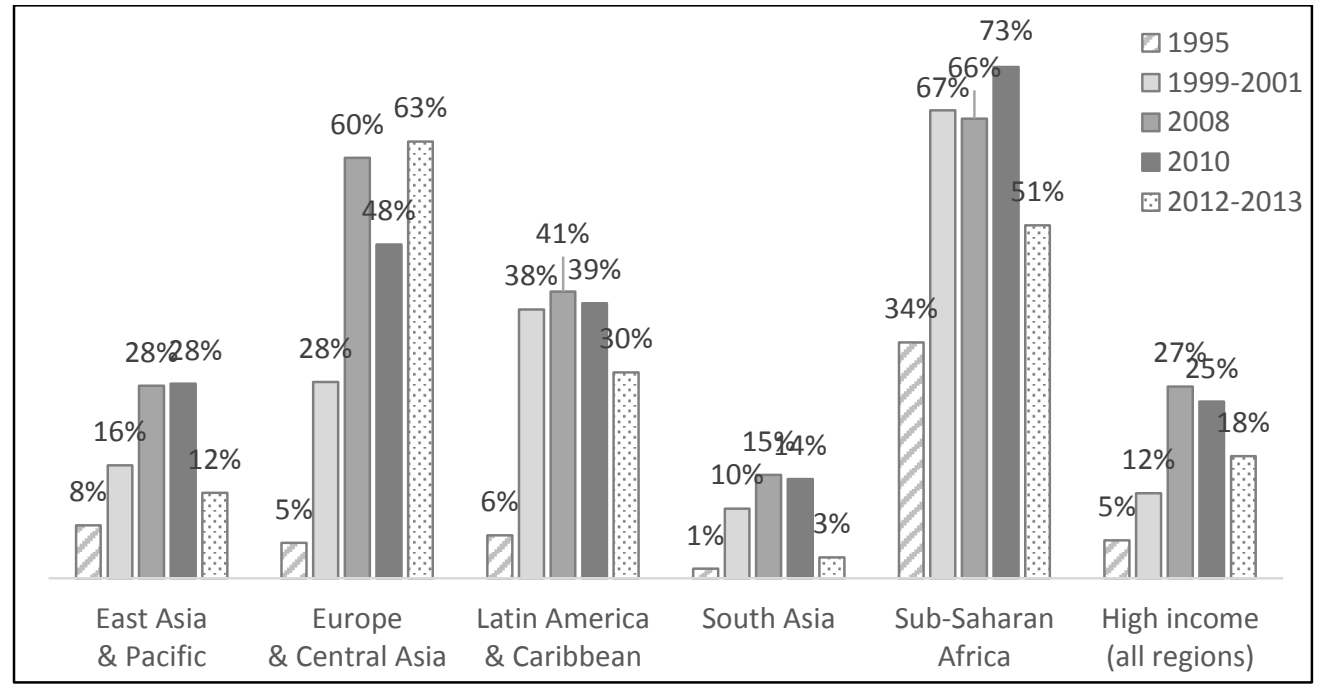

Note: The bars represent the median country in each region. High-income countries are grouped together in one category and excluded from the five regions. Estimates for 1999-2010 are based on a balanced sample of 65 developing and 28 high income countries, while estimates for 1995 and 2012-2013 are based on a smaller sample of countries (cf list of countries in Table A.1 in Appendix). Ownership is defined as the asset share of banks that are more than 50\% controlled by foreign owners, except for 1995 where ownership reflects the actual share owned by foreign banks.

Sources: Micco et al. (2007) for 1995; Bank regulation and Supervision Surveys for 1999-2010, Claessens and Van Horen (2015) for 2012-2013.

Figure 3.2. Median asset share of government-owned banks by region, 1995-2010

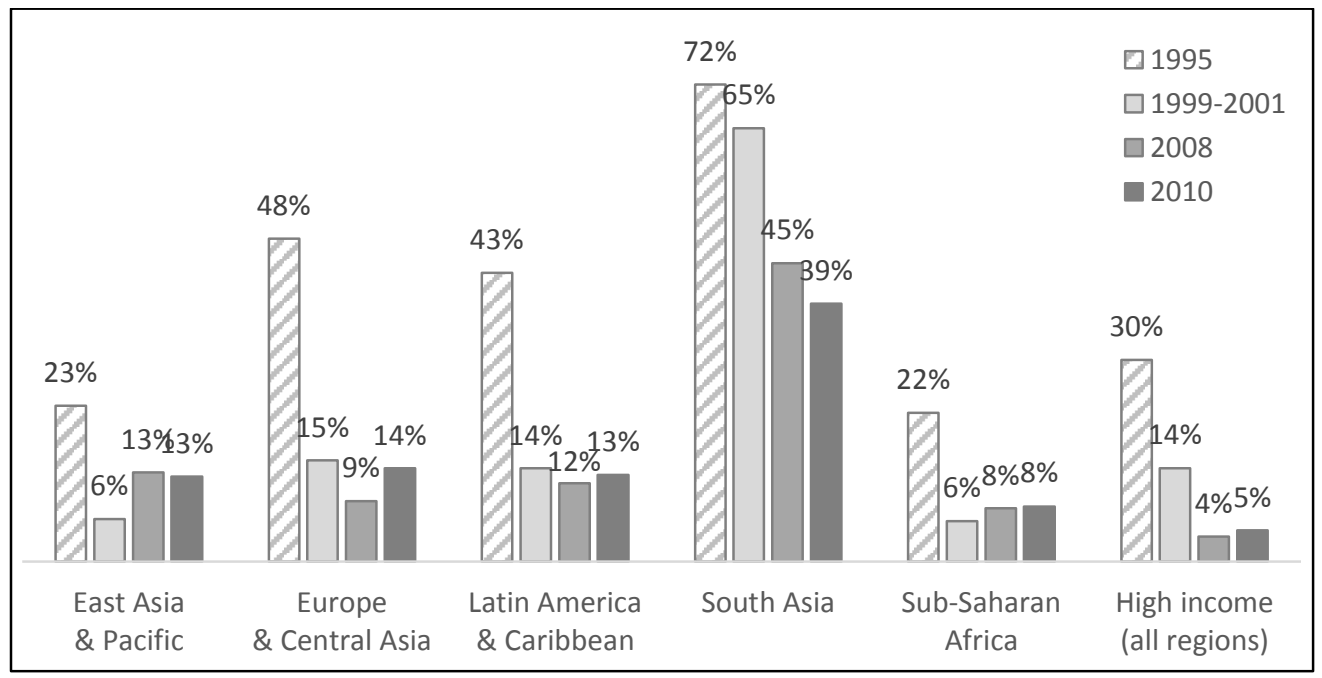

Note: The bars represent the median country in each region. High-income countries are grouped together in one category and excluded from the five regions. Estimates for 1999-2010 are based on a balanced sample of 65 developing and 28 high income countries, while estimates for 1995 are based on a smaller sample of countries (cf list of countries in Table A.1 in Appendix). Ownership is defined as the asset share of banks that are more than 50\% controlled by the government, except for 1995 where ownership reflects the actual share owned by the government.

Sources: Micco et al. (2007) for 1995; Bank regulation and Supervision surveys for 1999 onwards. 


\section{$\underline{\text { Appendix }}$}

Table A.1. Foreign and government ownership by country, 1995-2013

\begin{tabular}{lccccc|cccc} 
Income & \multicolumn{4}{c|}{ Foreign-owned banks } & \multicolumn{4}{c}{ State-owned banks } \\
\cline { 2 - 9 } group & 1995 & $1999-$ & 2008 & 2010 & $2012-$ & 1995 & $1999-$ & 2008 & 2010
\end{tabular}

East Asia \& Pacific

\begin{tabular}{llrrrrr|rrrr} 
Australia & HI & $6 \%$ & $17 \%$ & $16 \%$ & $13 \%$ & $2 \%$ & $44 \%$ & $0 \%$ & $0 \%$ & $0 \%$ \\
\hline Fiji & DVP & & $99 \%$ & $100 \%$ & $100 \%$ & & & $1 \%$ & $0 \%$ & $0 \%$ \\
\hline Indonesia & DVP & $4 \%$ & $7 \%$ & $33 \%$ & $34 \%$ & $26 \%$ & $64 \%$ & $44 \%$ & $38 \%$ & $38 \%$ \\
\hline Korea, Rep. & HI & $2 \%$ & $15 \%$ & $77 \%$ & $77 \%$ & $7 \%$ & $29 \%$ & $35 \%$ & $22 \%$ & $22 \%$ \\
\hline Malaysia & DVP & $25 \%$ & $19 \%$ & $22 \%$ & $22 \%$ & $18 \%$ & $3 \%$ & $0 \%$ & $0 \%$ & $0 \%$ \\
\hline New Zealand & HI & $99 \%$ & $99 \%$ & $96 \%$ & $95 \%$ & $95 \%$ & $0 \%$ & $0 \%$ & $2 \%$ & $3 \%$ \\
\hline Philippines & DVP & $8 \%$ & $14 \%$ & $12 \%$ & $12 \%$ & $1 \%$ & $29 \%$ & $12 \%$ & $13 \%$ & $12 \%$ \\
\hline Taiwan, China & HI & $0 \%$ & $0 \%$ & $11 \%$ & $11 \%$ & & $62 \%$ & $35 \%$ & $19 \%$ & $18 \%$ \\
\hline Thailand & DVP & $7 \%$ & $7 \%$ & $6 \%$ & $7 \%$ & $7 \%$ & $18 \%$ & $31 \%$ & $22 \%$ & $18 \%$ \\
\hline Tonga & DVP & & $100 \%$ & $87 \%$ & $87 \%$ & & & $0 \%$ & $14 \%$ & $13 \%$ \\
\hline
\end{tabular}

Europe and Central Asia (OECD)

\begin{tabular}{lcrrrrr|rrrr} 
Austria & HI & $5 \%$ & $5 \%$ & $23 \%$ & $18 \%$ & $26 \%$ & $22 \%$ & $2 \%$ & $5 \%$ & $12 \%$ \\
\hline Denmark & HI & $1 \%$ & $0 \%$ & $18 \%$ & $21 \%$ & $18 \%$ & $1 \%$ & $0 \%$ & $1 \%$ & $1 \%$ \\
\hline Estonia & HI & $81 \%$ & $92 \%$ & $99 \%$ & $99 \%$ & $97 \%$ & $0 \%$ & $0 \%$ & $0 \%$ & $0 \%$ \\
\hline Finland & HI & $0 \%$ & $7 \%$ & $72 \%$ & $74 \%$ & $85 \%$ & $32 \%$ & $11 \%$ & $0 \%$ & $0 \%$ \\
\hline Germany & HI & $5 \%$ & $4 \%$ & $13 \%$ & $12 \%$ & $12 \%$ & $27 \%$ & $42 \%$ & $35 \%$ & $32 \%$ \\
\hline Greece & HI & $2 \%$ & $8 \%$ & $22 \%$ & $21 \%$ & $7 \%$ & $86 \%$ & $18 \%$ & $10 \%$ & $11 \%$ \\
\hline Hungary & HI & $22 \%$ & $75 \%$ & $85 \%$ & $83 \%$ & $59 \%$ & $61 \%$ & $6 \%$ & $3 \%$ & $4 \%$ \\
\hline Iceland & HI & $0 \%$ & $0 \%$ & $0 \%$ & $0 \%$ & $0 \%$ & $95 \%$ & $32 \%$ & $28 \%$ & $41 \%$ \\
\hline Italy & HI & $2 \%$ & $5 \%$ & $18 \%$ & $18 \%$ & $6 \%$ & $34 \%$ & $14 \%$ & $0 \%$ & $0 \%$ \\
\hline Luxembourg & HI & $76 \%$ & $95 \%$ & $95 \%$ & $94 \%$ & $93 \%$ & $6 \%$ & $5 \%$ & $4 \%$ & $5 \%$ \\
\hline Norway & HI & $5 \%$ & $19 \%$ & $33 \%$ & $30 \%$ & $14 \%$ & $32 \%$ & $0 \%$ & $0 \%$ & $0 \%$ \\
\hline Poland & HI & $4 \%$ & $48 \%$ & $67 \%$ & $62 \%$ & $76 \%$ & $80 \%$ & $34 \%$ & $17 \%$ & $22 \%$ \\
\hline Portugal & HI & $13 \%$ & $15 \%$ & $21 \%$ & $22 \%$ & $23 \%$ & $25 \%$ & $22 \%$ & $21 \%$ & $23 \%$ \\
\hline Slovak Republic & HI & $9 \%$ & $71 \%$ & $96 \%$ & $94 \%$ & $83 \%$ & $84 \%$ & $15 \%$ & $1 \%$ & $1 \%$ \\
\hline Slovenia & HI & $7 \%$ & $13 \%$ & $31 \%$ & $28 \%$ & $26 \%$ & $48 \%$ & $26 \%$ & $51 \%$ & $51 \%$ \\
\hline Spain & HI & $6 \%$ & $10 \%$ & $11 \%$ & $8 \%$ & $2 \%$ & $3 \%$ & $0 \%$ & $0 \%$ & $0 \%$ \\
\hline Switzerland & HI & $2 \%$ & $10 \%$ & $11 \%$ & $12 \%$ & $2 \%$ & $21 \%$ & $15 \%$ & $13 \%$ & $16 \%$ \\
\hline Turkey & DVP & $0 \%$ & $35 \%$ & $17 \%$ & $17 \%$ & $13 \%$ & $54 \%$ & $33 \%$ & $31 \%$ & $32 \%$ \\
\hline United Kingdom & HI & $7 \%$ & $46 \%$ & $24 \%$ & $18 \%$ & $15 \%$ & $0 \%$ & $0 \%$ & $1 \%$ & $26 \%$ \\
\hline
\end{tabular}

Europe and Central Asia (Non-OECD)

\begin{tabular}{llllll|lll} 
Armenia & DVP & $51 \%$ & $60 \%$ & $67 \%$ & $84 \%$ & $1 \%$ & $0 \%$ & $0 \%$ \\
\hline
\end{tabular}




\begin{tabular}{llrrrrr|rrrr} 
Belarus & DVP & $0 \%$ & $14 \%$ & $22 \%$ & $27 \%$ & $32 \%$ & $71 \%$ & $71 \%$ & $78 \%$ & $72 \%$ \\
\hline Bosnia and Herzegovina & DVP & & $54 \%$ & $93 \%$ & $92 \%$ & $86 \%$ & & $20 \%$ & $1 \%$ & $1 \%$ \\
\hline Bulgaria & DVP & $8 \%$ & $74 \%$ & $84 \%$ & $81 \%$ & $66 \%$ & $70 \%$ & $18 \%$ & $2 \%$ & $3 \%$ \\
\hline Croatia & HI & $10 \%$ & $48 \%$ & $91 \%$ & $89 \%$ & $90 \%$ & $71 \%$ & $21 \%$ & $4 \%$ & $4 \%$ \\
\hline Cyprus & HI & $28 \%$ & $12 \%$ & $44 \%$ & $35 \%$ & & $2 \%$ & $4 \%$ & $1 \%$ & $1 \%$ \\
\hline Kazakhstan & DVP & $13 \%$ & $15 \%$ & $13 \%$ & $17 \%$ & $15 \%$ & $19 \%$ & $1 \%$ & $1 \%$ & $23 \%$ \\
\hline Kyrgyz Republic & DVP & & $25 \%$ & $72 \%$ & $46 \%$ & $78 \%$ & & $15 \%$ & $18 \%$ & $20 \%$ \\
\hline Latvia & DVP & $18 \%$ & $65 \%$ & $68 \%$ & $69 \%$ & $59 \%$ & $25 \%$ & $3 \%$ & $11 \%$ & $16 \%$ \\
\hline Liechtenstein & HI & $0 \%$ & $2 \%$ & $6 \%$ & $4 \%$ & & $39 \%$ & $18 \%$ & $30 \%$ & $29 \%$ \\
\hline Lithuania & DVP & $19 \%$ & $63 \%$ & $86 \%$ & $81 \%$ & $93 \%$ & $43 \%$ & $28 \%$ & $0 \%$ & $0 \%$ \\
\hline Moldova & DVP & & $35 \%$ & $32 \%$ & $42 \%$ & $34 \%$ & & $10 \%$ & $9 \%$ & $13 \%$ \\
\hline Romania & DVP & $0 \%$ & $28 \%$ & $88 \%$ & $84 \%$ & $81 \%$ & $89 \%$ & $56 \%$ & $6 \%$ & $8 \%$ \\
\hline Russian Federation & DVP & $2 \%$ & $9 \%$ & $19 \%$ & $18 \%$ & $9 \%$ & $54 \%$ & $52 \%$ & $38 \%$ & $41 \%$ \\
\hline Tajikistan & DVP & & $28 \%$ & $7 \%$ & $6 \%$ & & & $6 \%$ & $12 \%$ & $14 \%$ \\
\hline Ukraine & DVP & $0 \%$ & $11 \%$ & $51 \%$ & $48 \%$ & $32 \%$ & $35 \%$ & $12 \%$ & $12 \%$ & $17 \%$ \\
\hline
\end{tabular}

\section{Latin America and \& Caribbean}

\begin{tabular}{llrrrrr|rrrr} 
Argentina & DVP & $26 \%$ & $40 \%$ & $31 \%$ & $26 \%$ & $27 \%$ & $50 \%$ & $31 \%$ & $38 \%$ & $44 \%$ \\
\hline Belize & DVP & & $95 \%$ & $100 \%$ & $100 \%$ & & & $0 \%$ & $0 \%$ & $0 \%$ \\
\hline Brazil & DVP & $9 \%$ & $23 \%$ & $21 \%$ & $18 \%$ & $16 \%$ & $60 \%$ & $42 \%$ & $40 \%$ & $44 \%$ \\
\hline Chile & DVP & $31 \%$ & $39 \%$ & $41 \%$ & $39 \%$ & $27 \%$ & $19 \%$ & $13 \%$ & $15 \%$ & $19 \%$ \\
\hline Colombia & DVP & $6 \%$ & $22 \%$ & $22 \%$ & $20 \%$ & $14 \%$ & $37 \%$ & $18 \%$ & $6 \%$ & $6 \%$ \\
\hline Costa Rica & DVP & $0 \%$ & $23 \%$ & $36 \%$ & $31 \%$ & $29 \%$ & $78 \%$ & $62 \%$ & $50 \%$ & $54 \%$ \\
\hline Ecuador & DVP & & $70 \%$ & $3 \%$ & $2 \%$ & $16 \%$ & & $14 \%$ & $12 \%$ & $17 \%$ \\
\hline El Salvador & DVP & $1 \%$ & $12 \%$ & $94 \%$ & $93 \%$ & $98 \%$ & $31 \%$ & $6 \%$ & $5 \%$ & $6 \%$ \\
\hline Guatemala & DVP & $6 \%$ & $7 \%$ & $11 \%$ & $10 \%$ & $31 \%$ & $6 \%$ & $5 \%$ & $2 \%$ & $2 \%$ \\
\hline Guyana & DVP & $0 \%$ & $18 \%$ & $57 \%$ & $56 \%$ & & $59 \%$ & $17 \%$ & $0 \%$ & $0 \%$ \\
\hline Honduras & DVP & $2 \%$ & $10 \%$ & $50 \%$ & $50 \%$ & $55 \%$ & $0 \%$ & $1 \%$ & $2 \%$ & $1 \%$ \\
\hline Jamaica & DVP & $24 \%$ & $44 \%$ & $94 \%$ & $95 \%$ & $93 \%$ & $4 \%$ & $56 \%$ & $0 \%$ & $0 \%$ \\
\hline Mexico & DVP & $2 \%$ & $51 \%$ & $84 \%$ & $85 \%$ & $71 \%$ & $53 \%$ & $13 \%$ & $14 \%$ & $13 \%$ \\
\hline Peru & DVP & $52 \%$ & $41 \%$ & $51 \%$ & $49 \%$ & $50 \%$ & $28 \%$ & $1 \%$ & $0 \%$ & $0 \%$ \\
\hline Suriname & DVP & & $26 \%$ & $25 \%$ & $21 \%$ & & & $31 \%$ & $37 \%$ & $33 \%$ \\
\hline Trinidad and Tobago & HI & $14 \%$ & $5 \%$ & $52 \%$ & $46 \%$ & & $0 \%$ & $15 \%$ & $17 \%$ & $24 \%$ \\
\hline Uruguay & DVP & $24 \%$ & $43 \%$ & $52 \%$ & $54 \%$ & $73 \%$ & $63 \%$ & $43 \%$ & $48 \%$ & $46 \%$ \\
\hline Venezuela, RB & DVP & $5 \%$ & $38 \%$ & $26 \%$ & $17 \%$ & $16 \%$ & $63 \%$ & $6 \%$ & $12 \%$ & $33 \%$ \\
\hline
\end{tabular}

\section{South Asia}

\begin{tabular}{llrrrrr|rrrr} 
Bangladesh & DVP & $0 \%$ & $6 \%$ & $8 \%$ & $7 \%$ & $3 \%$ & $72 \%$ & $70 \%$ & $38 \%$ & $34 \%$ \\
\hline Bhutan & DVP & & $10 \%$ & $0 \%$ & $6 \%$ & & & $65 \%$ & $47 \%$ & $48 \%$ \\
\hline India & DVP & $1 \%$ & $4 \%$ & $8 \%$ & $7 \%$ & $3 \%$ & $77 \%$ & $78 \%$ & $70 \%$ & $74 \%$ \\
\hline Maldives & DVP & & $25 \%$ & $55 \%$ & $61 \%$ & & & $75 \%$ & $45 \%$ & $39 \%$ \\
\hline Nepal & DVP & $39 \%$ & $35 \%$ & $18 \%$ & $17 \%$ & $12 \%$ & $0 \%$ & $20 \%$ & $29 \%$ & $24 \%$ \\
\hline Pakistan & DVP & $1 \%$ & $20 \%$ & $54 \%$ & $59 \%$ & $52 \%$ & $76 \%$ & $54 \%$ & $21 \%$ & $21 \%$ \\
\hline
\end{tabular}


Sri Lanka

DVP

$2 \%$ $0 \%$ $15 \%$

Sub-Saharan Africa

\begin{tabular}{|c|c|c|c|c|c|c|c|c|c|c|}
\hline Benin & DVP & & $91 \%$ & $66 \%$ & $73 \%$ & & & $0 \%$ & $8 \%$ & $8 \%$ \\
\hline Botswana & DVP & $80 \%$ & $99 \%$ & $94 \%$ & $93 \%$ & $79 \%$ & $4 \%$ & $1 \%$ & $7 \%$ & $7 \%$ \\
\hline Burkina Faso & DVP & & $56 \%$ & $66 \%$ & $73 \%$ & & & $0 \%$ & $8 \%$ & $8 \%$ \\
\hline Burundi & DVP & $39 \%$ & $0 \%$ & $12 \%$ & $16 \%$ & & $19 \%$ & $63 \%$ & $49 \%$ & $49 \%$ \\
\hline Côte d'Ivoire & DVP & $20 \%$ & $84 \%$ & $66 \%$ & $73 \%$ & & $62 \%$ & $11 \%$ & $8 \%$ & $8 \%$ \\
\hline Gambia, The & DVP & & $86 \%$ & $76 \%$ & $80 \%$ & & & $0 \%$ & $0 \%$ & $0 \%$ \\
\hline Ghana & DVP & $28 \%$ & $54 \%$ & $53 \%$ & $51 \%$ & $69 \%$ & $68 \%$ & $25 \%$ & $10 \%$ & $10 \%$ \\
\hline Guinea-Bissau & DVP & & $100 \%$ & $66 \%$ & $73 \%$ & & & $0 \%$ & $8 \%$ & $8 \%$ \\
\hline Kenya & DVP & $27 \%$ & $39 \%$ & $40 \%$ & $37 \%$ & $33 \%$ & $15 \%$ & $1 \%$ & $5 \%$ & $5 \%$ \\
\hline Lesotho & DVP & & $75 \%$ & $97 \%$ & $97 \%$ & & & $26 \%$ & $3 \%$ & $3 \%$ \\
\hline Madagascar & DVP & $42 \%$ & $68 \%$ & $100 \%$ & $100 \%$ & $100 \%$ & $42 \%$ & $0 \%$ & $0 \%$ & $0 \%$ \\
\hline Malawi & DVP & & $8 \%$ & $30 \%$ & $29 \%$ & $34 \%$ & & $49 \%$ & $8 \%$ & $9 \%$ \\
\hline Mali & DVP & $41 \%$ & $67 \%$ & $66 \%$ & $73 \%$ & & $38 \%$ & $22 \%$ & $8 \%$ & $8 \%$ \\
\hline Niger & DVP & & $73 \%$ & $66 \%$ & $73 \%$ & & & $0 \%$ & $8 \%$ & $8 \%$ \\
\hline Nigeria & DVP & $10 \%$ & $0 \%$ & $4 \%$ & $6 \%$ & $18 \%$ & $0 \%$ & $9 \%$ & $0 \%$ & $0 \%$ \\
\hline Senegal & DVP & & $79 \%$ & $66 \%$ & $73 \%$ & $94 \%$ & & $0 \%$ & $8 \%$ & $8 \%$ \\
\hline Seychelles & DVP & & $60 \%$ & $70 \%$ & $69 \%$ & $65 \%$ & & $40 \%$ & $30 \%$ & $31 \%$ \\
\hline South Africa & DVP & $0 \%$ & $6 \%$ & $30 \%$ & $28 \%$ & $25 \%$ & $2 \%$ & $0 \%$ & $0 \%$ & $0 \%$ \\
\hline Swaziland & DVP & & $86 \%$ & $84 \%$ & $84 \%$ & $89 \%$ & & $14 \%$ & $16 \%$ & $16 \%$ \\
\hline Togo & DVP & & $18 \%$ & $66 \%$ & $73 \%$ & $0 \%$ & & $51 \%$ & $8 \%$ & $8 \%$ \\
\hline Zimbabwe & DVP & $46 \%$ & $28 \%$ & $84 \%$ & $46 \%$ & $36 \%$ & $26 \%$ & $6 \%$ & $1 \%$ & $8 \%$ \\
\hline
\end{tabular}

Notes: Income groups follow the 2010 World Bank analytical classification. Government (respectively foreign) ownership is defined as the asset share of banks that are more than $50 \%$ controlled by the government (respectively foreign owners), except for 1995 where ownership reflects the actual share owned by the government (respectively foreign owners).

Sources: Micco, Panizza and Yanez (2007) for 1995 data, Regulation and Supervision surveys (World Bank) for 1999-2010 data, Claessens and Van Horen (2015) for 2012-2013 data. 